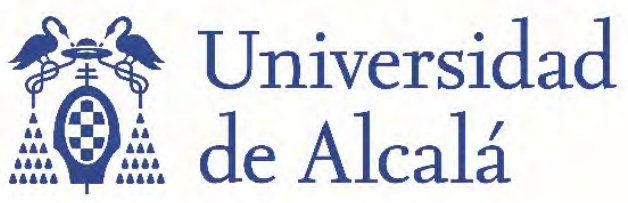

BIBLIOTECA

Document downloaded from the institutional repository of the University of Alcala: http://dspace.uah.es/

This is a postprint version of the following published document:

Pérez-Míguez, R., Marina, M.L. \& Castro-Puyana, M. 2016, "Capillary electrophoresis determination of non-protein amino acids as quality markers in foods", Journal of Chromatography A, vol. 1428, pp. 97-114.

Available at http://dx.doi.org/10.1016/j.chroma.2015.07.078

(C) 2015 Elsevier
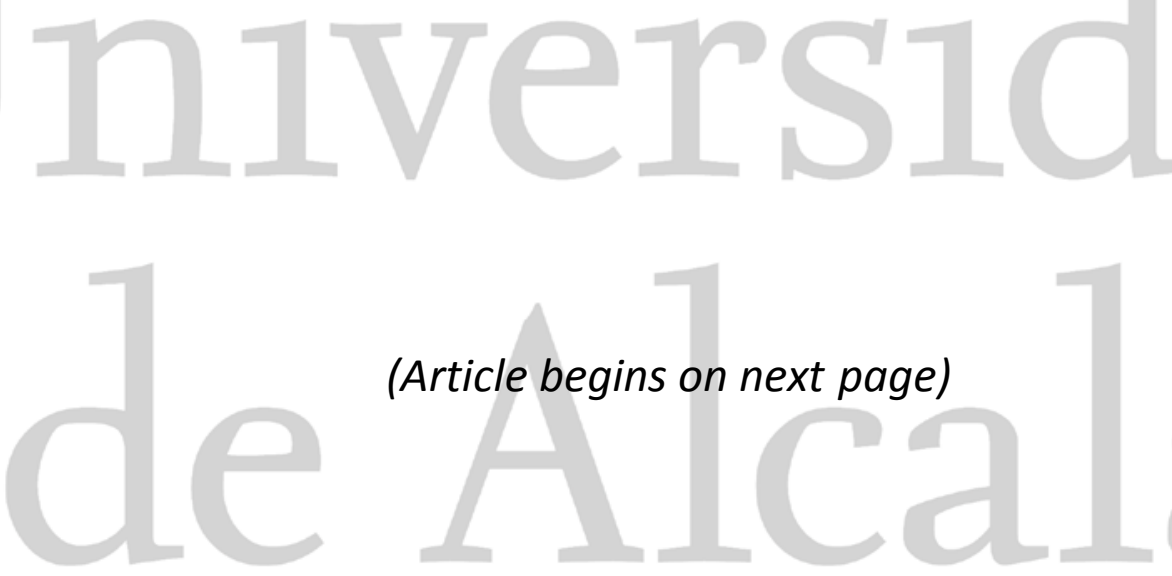

(Article begins on next page)

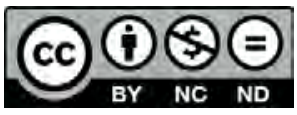

This work is licensed under a

Creative Commons Attribution-NonCommercial-NoDerivatives

4.0 International License. 


\title{
CAPILLARY ELECTROPHORESIS DETERMINATION OF NON PROTEIN AMINO ACIDS AS QUALITY MARKERS IN FOODS
}

\author{
Raquel Pérez-Míguez, María Luisa Marina, María Castro-Puyana*
}

Department of Analytical Chemistry, Physical Chemistry and Chemical Engineering.

Faculty of Biology, Environmental Sciences and Chemistry. University of Alcalá, Ctra. Madrid-Barcelona Km. 33.600, 28871 Alcalá de Henares (Madrid), Spain.

Keywords: capillary electrophoresis, non-protein amino acids, foods, quality markers, microchip electrophoresis.

Correspondence: Dr. María Castro-Puyana, Department of Analytical Chemistry, Physical Chemistry and Chemical Engineering. Faculty of Biology, Environmental Sciences and Chemistry. University of Alcalá, Ctra. Madrid-Barcelona Km. 33.600, 28871 Alcalá de Henares (Madrid), Spain.

E-mail: maria.castrop@,uah.es

Tfn/Fax: 34-918856430/34-918854971 


\begin{abstract}
Non-protein amino acids mainly exist in food as products formed during food processing, as metabolic intermediates or as additives to increase nutritional and functional properties of food. This fact makes their analysis and determination an attractive field in food science since they can give interesting information on the quality and safety of foods. This article presents a comprehensive review devoted to describe the latest advances in the development of (achiral and chiral) analytical methodologies by capillary electrophoresis and microchip capillary electrophoresis for the analysis of nonprotein amino acids in a variety of food samples. Most relevant information related to sample treatment, experimental separation and detection conditions, preconcentration strategies and limits of detection will be provided.
\end{abstract}




\section{Introduction}

The determination of protein amino acids has been exploited for years in the food field because they can provide relevant information on the quality and safety of food samples [1,2,3]. In addition to these compounds, it is also possible to find other amino acids of non-protein origin in foods which exist as metabolic intermediates, as products formed during food processing or as additives in food to increase some nutritional and functional properties $[4,5]$. Non-protein amino acids have been defined as those amino acids that are not found in protein main chain either for lack of a specific transfer RNA and codon triplet or because they do not arise from protein amino acids by posttranslational modification [6]. Even though non-protein amino acids have been studied to a lesser extent, they have also shown to play an important role in the quality and safety of foods. Thus, different research works have demonstrated the relevance of determining non-protein amino acids to detect food adulterations, to investigate fermentation, storage and thermal treatments, to evaluate the nutritional quality of foods or to determine their toxic effects $[7,8,9,10,11,12]$.

Non-protein amino acids can be chiral having one or more chiral centers providing, therefore, at least one pair of enantiomers. Obviously, each enantiomer can originate different effects when interacting with chiral environments as enzymes, proteins and receptors [3]. Although the L-enantiomers are the natural form of amino acids, their exposure to certain processing conditions may originate their racemization to Denantiomers. Processing-induced amino acid racemization includes from heat treatments, fermentation or storage to microbiological processes $[13,14]$. Moreover, D-enantiomers can be found in foods as a consequence of the fraudulent addition of racemic mixtures of non protein amino acids in supplemented foodstuffs where regulations establish the use of pure L-enantiomers. The use of racemic mixtures originates economical benefits due 
to the minor cost that these mixtures have with respect to the use of pure enantiomers. In general terms, enantioselective separations may be relevant in different food areas in order to propose quality markers to assess food authenticity and to detect adulterations, to evaluate the effects of processing, fermentation, microbiological activity and storage, to analyze chiral metabolites and to investigate health-promoting compounds or evaluate flavor and fragrance aromas $[2,3,15,16]$. In the specific case of chiral non-protein amino acids, the analysis of their enantiomers in foods is a very useful tool not only to assess food quality and authenticity [17], but also to evaluate processing, manufacturing of food supplements and detect microbiological contaminations $[12,18]$.

Undoubtedly, these research activities are of great interest in the area of Food Analysis due to the increasing concern of consumers about the quality of food. Therefore, taking into account that assuring product food quality, authenticity, and safety is the main demand in the food field, there is an increasing need of analytical methodologies enabling the determination of non-protein amino acids in foodstuffs. Among the advanced analytical techniques that can be used to solve some of the challenges that Food Science has to face, Capillary Electrophoresis (CE) has already demonstrated its high potential for the (achiral and chiral) determination of many compounds in foods, including amino acids, to ensure compliance with food and trade laws [1,19,20,21]. Among the CE modes used to determine non protein amino acids in food samples, CZE (based on the free mobility of analytes in the aqueous solution under an applied electric field) and MEKC (based on the combination of electrokinetic migration and the partitioning mechanism between the bulk solution and micelles) are the most employed, whereas EKC and CEC (based on the interaction of each enantiomer with a chiral selector present in the mobile phase or with a chiral stationary phase, respectively) are the most employed CE modes to achieve an enantiomeric separation. 
The present article reviews the most recent advances in the analysis of non protein amino acids in foods using capillary electrophoretic methodologies (CZE, MEKC, EKC, and CEC) and microchip electrophoresis under achiral as well as chiral conditions covering the research articles published during the period February 2007 to February 2015, following the previous article published by our research group on this topic [1]. To make easier the discussion of the literature data and demonstrate the usefulness of CE to face different challenges related to food quality, this review has been divided in two different sections focused on the achiral and chiral determination of non-protein amino acids in foods. These sections gather the non-protein amino acids according to their structure and describe the different CE approaches (including experimental conditions, preconcentration strategies and sample treatments) developed to analyze these compounds in a great variety of food samples.

\section{Determination of non-protein amino acids in foods by $\mathrm{CE}$ under achiral} conditions

With the aim of providing an updated view on the achiral CE methodologies developed for the analysis of non-protein amino acids in the period of time reviewed in this article, Table 1 summarizes the main characteristics of the developed methodologies. It can be observed that, as expected, most of the research articles published employed CZE as separation mode, although the use of other modes such as electrokinetic chromatography using micelles as pseudostationary phase (MEKC mode), CEC and microchip capillary electrophoresis (MCE) has also been reported. With respect to the detection systems, UV and fluorescence are the most popular despite the need to include an additional analytical step (derivatization) to add a chromophore or fluorophore group into the molecule. $o$-phthaldialdehyde (OPA), fluorescein isothiocyanate (FITC), 4- 
chloro-7-nitrobenzofurazan (NDB-Cl) or 9-fluoroenylmethylchloroformate (FMOC), among others, have mainly been used as reagents for the derivatization of non-protein amino acids. To a lesser extent, mass spectrometry (MS), inductively coupled plasmaMS (ICP-MS), electrochemical and capacitively coupled contactless conductivity $\left(C^{4} \mathrm{D}\right)$ have also been reported as detection systems coupled to $\mathrm{CE}$ for determining non-protein amino acids. It should be highlighted that a broad range of food samples, from beverages (such as tea, soy based beverages, cow milk, energy drinks, etc), to flour products, shellfish, vegetables (tomato, brassica or allium species, etc), rice, meat products, or vegetable and olive oils have been analyzed by the developed CE approaches as shown in Table 1. The achiral determination of non-protein amino acids in these food matrices has been carried out mainly with quality control purposes. Thus, research works focused on the detection of adulterations, the study of the effects of fermentation, storage or thermal treatments, or the evaluation of the nutritional quality of different foods samples have enabled to point out these compounds as potential markers of food quality.

A more detailed description of the different achiral CE methodologies developed for the determination of non protein amino acids and their applications in the area of Food Analysis will be provided next. 
Table 1. Characteristics of the analytical methodologies developed for the achiral determination of non protein amino acids in foods by CE.

\begin{tabular}{|c|c|c|c|c|c|c|c|}
\hline Classification & Name (Abbr.) & $\begin{array}{l}\text { CE-mode/detection } \\
\text { Separation conditions }\end{array}$ & $\begin{array}{l}\text { Separation } \\
\text { from: }\end{array}$ & Sample treatment & Application & LOD* & Ref \\
\hline \multirow{6}{*}{$\begin{array}{l}\text { Aliphatic } \\
\text { monoamio- } \\
\text { monocarboxyl } \\
\text { aminoacids }\end{array}$} & \multirow[t]{6}{*}{$\begin{array}{l}\gamma \text { - aminobutyric acid } \\
\text { (GABA) }\end{array}$} & $\begin{array}{l}\text { CZE-Fluorescence } \\
\left(\lambda_{\mathrm{ex}} 200-400 \mathrm{~nm} ; \lambda_{\mathrm{em}} 495 \mathrm{~nm}\right)\end{array}$ & \multirow[t]{2}{*}{ Ala } & \multirow[t]{2}{*}{$\begin{array}{l}\text { Boil, filtration, and dilution with } \\
\text { water before in-capillary } \\
\text { derivatization with OPA/2-ME }\end{array}$} & \multirow[t]{2}{*}{$\begin{array}{l}\text { Determination of GABA and } \\
\text { Ala in tea samples }\end{array}$} & \multirow[t]{2}{*}{$0.004 \mu \mathrm{M}$} & \multirow[t]{2}{*}{ [22] } \\
\hline & & $\begin{array}{l}30 \mathrm{mM} \text { sodium borate }(\mathrm{pH} 10.0) \\
\text { capillary, } 50 \mu \mathrm{m} \times 65 \mathrm{~cm} ; 21 \mathrm{kV} \\
23^{\circ} \mathrm{C}\end{array}$ & & & & & \\
\hline & & $\begin{array}{l}\text { CZE-Fluorescence } \\
\left(\lambda_{\mathrm{ex}} 200-400 \mathrm{~nm} ; \lambda_{\mathrm{em}} 495 \mathrm{~nm}\right)\end{array}$ & \multirow[t]{2}{*}{ Ala } & \multirow{2}{*}{$\begin{array}{l}\text { Boil, filtration, and dilution with } \\
\mathrm{ACN}: 0.1 \mathrm{mM} \mathrm{NaCl}(2: 1 \mathrm{v} / \mathrm{v}) \\
\text { before in-capillary derivatization } \\
\text { with } \mathrm{OPA} / 2-\mathrm{ME}\end{array}$} & \multirow[t]{2}{*}{$\begin{array}{l}\text { Determination of GABA and } \\
\text { Ala in tea samples }\end{array}$} & \multirow[t]{2}{*}{$0.7 \mathrm{nM}$} & \multirow[t]{2}{*}{ [23] } \\
\hline & & $\begin{array}{l}50 \mathrm{mM} \text { sodium borate }(\mathrm{pH} 10.0) \\
\text { capillary, } 50 \mu \mathrm{m} \text { x } 65 \mathrm{~cm} ; 21 \mathrm{kV} \\
23^{\circ} \mathrm{C}\end{array}$ & & & & & \\
\hline & & & \multirow[t]{2}{*}{$\begin{array}{l}16 \text { protein } \\
\text { amino acids }\end{array}$} & $\begin{array}{l}\text { Extraction with } 75 \% \text { ethanol } \\
\text { (v/v), ultrasonication. }\end{array}$ & \multirow{2}{*}{$\begin{array}{l}\text { Simultaneous determination } \\
\text { of free amino acids in several } \\
\text { types of royal jelly products } \\
\text { and honey }\end{array}$} & \multirow[t]{2}{*}{$0.84 \mu \mathrm{g} / \mathrm{g}$} & \multirow[t]{2}{*}{ [24] } \\
\hline & & $\begin{array}{l}1 \mathrm{mM} \text { formic acid (pH 1.8); capillary, } \\
50 \mu \mathrm{m} \times 100 \mathrm{~cm} ; 30 \mathrm{kV}, 20^{\circ} \mathrm{C}\end{array}$ & & $\begin{array}{l}\text { centrifugation, addition of } 1 \mathrm{M} \\
\mathrm{HCl}(0.9 \mathrm{~mL} \text { supernatant: } 0.1 \mathrm{~mL} \\
\mathrm{HCl}) \text { prior to CE analysis }\end{array}$ & & & \\
\hline \multirow{5}{*}{$\begin{array}{l}\text { Aliphatic amino } \\
\text { acids with } \\
\text { nitrogen in the } \\
\text { side chain }\end{array}$} & \multirow[t]{5}{*}{ Theanine (Thea) } & MEKC-UV & \multirow{2}{*}{$\begin{array}{l}7 \text { Catechins, } 3 \\
\text { xanthines, } \\
\text { gallic acid, } \\
\text { vitamin C, } \\
\text { and theaflavin }\end{array}$} & Different treatment for making & \multirow{2}{*}{$\begin{array}{l}\text { Determination of tea } \\
\text { fermentation through } \\
\text { simultaneous analysis of } \\
\text { catechins, xanthines, gallic } \\
\text { acid, vitamin C, thea and } \\
\text { theaflavins }\end{array}$} & \multirow[t]{2}{*}{-} & \multirow[t]{2}{*}{ [25] } \\
\hline & & $\begin{array}{l}10 \mathrm{mM} \text { sodium dihydrogenphosphate } \\
+4 \mathrm{mM} \text { sodium borate }+45 \mathrm{mM} \text { SDS } \\
+0.5 \% \text { ethanol }(\mathrm{pH} 7.0) \text {; capillary, } 50 \\
\mu \mathrm{m} \times 38.5 \mathrm{~cm} ; 20 \mathrm{kV} ; 30^{\circ} \mathrm{C}\end{array}$ & & $\begin{array}{l}\text { fermented and fully-fermented } \\
\text { tea, drying, water extraction } \\
\text { (under orbital shaking), and } \\
\text { filtration before CE injection }\end{array}$ & & & \\
\hline & & $\begin{array}{l}\text { MEKC-LIF } \\
\left(\lambda_{\mathrm{ex}} 488 \mathrm{~nm} ; \lambda_{\mathrm{em}} 520 \mathrm{~nm}\right)\end{array}$ & \multirow[t]{3}{*}{$\begin{array}{l}13 \text { protein } \\
\text { amino acids }+ \\
\text { GABA }\end{array}$} & \multirow[t]{3}{*}{$\begin{array}{l}\text { Extraction with hot water, } \\
\text { centrifugation, filtration and pre- } \\
\text { capillary derivatization with } \\
\text { NDB-Cl }\end{array}$} & \multirow[t]{3}{*}{$\begin{array}{l}\text { Simultaneous determination } \\
\text { of free amino acids in } \\
\text { different tea leaves }\end{array}$} & \multirow[t]{3}{*}{$0.1 \mathrm{ng} / \mathrm{L}$} & \multirow[t]{3}{*}{ [26] } \\
\hline & & $\begin{array}{l}20 \mathrm{mM} \text { Brij } 35+10 \% \mathrm{ACN}(\mathrm{v} / \mathrm{v}) \text { in } \\
20 \mathrm{mM} \text { sodium borate }(\mathrm{pH}\end{array}$ & & & & & \\
\hline & & $\begin{array}{l}8.5) \text {; capillary, } 75 \mu \mathrm{m} \times 40 \mathrm{~cm} ; 20 \mathrm{kV} \text {; } \\
25^{\circ} \mathrm{C}\end{array}$ & & & & & \\
\hline
\end{tabular}


Table 1. Continued

\begin{tabular}{|c|c|c|c|c|c|c|c|}
\hline Classification & Name (Abbr.) & $\begin{array}{l}\text { CE-mode/detection } \\
\text { Separation conditions }\end{array}$ & $\begin{array}{l}\text { Separation } \\
\text { from: }\end{array}$ & Sample treatment & Application & LOD* & Ref. \\
\hline \multirow{6}{*}{$\begin{array}{l}\text { Heterocycle } \\
\text { amino acids }\end{array}$} & Homoarginine (Har) & $\begin{array}{l}\text { CZE-UV }(200 \mathrm{~nm}) \\
18.5 \mathrm{mM} \text { sodium borate }(\mathrm{pH} 9.2) \\
+10 \mathrm{mM} \text { sodium sulfate; } \\
\text { capillary, } 50 \mu \mathrm{m} \text { x } 42 \mathrm{~cm} ; 25 \mathrm{kV} \text {, } \\
30^{\circ} \mathrm{C}\end{array}$ & - & $\begin{array}{l}\text { Extraction with ethanol/water } \\
(6: 4 \mathrm{v} / \mathrm{v}) \text { and centrifugation prior } \\
\text { to } \mathrm{CE} \text { analysis }\end{array}$ & $\begin{array}{l}\text { Analysis of Har accumulation } \\
\text { in Grass Pea dry Seeds }\end{array}$ & - & [27] \\
\hline & $\begin{array}{l}\beta \text {-N-methylamino-L- } \\
\text { alanine (BMAA) }\end{array}$ & $\begin{array}{l}\text { CZE-UV }(192 \mathrm{~nm}) \\
5 \mathrm{mM} \text { sodium borate }(\mathrm{pH} 9.0) ; 75 \\
\mu \mathrm{m} \times 50 \mathrm{~cm} ; 25 \mathrm{kV}, 25^{\circ} \mathrm{C}\end{array}$ & - & $\begin{array}{l}\text { Sequential extraction using TCA } \\
\text { and microwave-digested with } \\
\text { HCL, drying, and solution in } \\
\text { deuterated water }\end{array}$ & $\begin{array}{l}\text { Determination of BMAA in } \\
18 \text { strains of estuarine } \\
\text { cyanobacteria }\end{array}$ & $0.5 \mathrm{mg} / \mathrm{L}$ & [28] \\
\hline & Ornithine (Orn) & $\begin{array}{l}\text { CZE-MS }{ }^{2} \\
0.1 \mathrm{M} \text { formic acid }(\mathrm{pH} 2.0) \\
\text { capillary, } 50 \mu \mathrm{m} \text { x } 60 \mathrm{~cm} ; 25 \mathrm{kV} \text {, } \\
25^{\circ} \mathrm{C}\end{array}$ & $\begin{array}{l}5 \text { non- } \\
\text { protein } \\
\text { amino acids } \\
\text { ( } \beta \text {-ala, } \\
\text { GABA, allo, } \\
\text { cit, pyro) }\end{array}$ & $\begin{array}{l}\text { Extraction with } \\
\text { methanol/chloroform }(2: 1 \mathrm{v} / \mathrm{v}) \text {, } \\
\text { centrifugation, drying, butanol } \\
\text { derivatization, evaporation and } \\
\text { dilution in ACN: water }(40: 60 \\
\mathrm{v} / \mathrm{v}) \text {. }\end{array}$ & $\begin{array}{l}\text { Potential of non-protein } \\
\text { amino acids as novel markers } \\
\text { of adulterations of } \\
\text { olive oils with seeds oils }\end{array}$ & $\begin{array}{l}0.04 \mathrm{ng} / \mathrm{g}(\mathrm{Orn}, \beta- \\
\text { ala, GABA, allo) } \\
0.19 \mathrm{ng} / \mathrm{g} \text { (cit, } \\
\text { pyro) }\end{array}$ & {$[7]$} \\
\hline & Furosine & $\begin{array}{l}\text { CZE-UV }(280 \mathrm{~nm}) \\
50 \mathrm{mM} \text { sodium phosphate }(\mathrm{pH} \\
7.0) \text {; bubble capillary, } 50 \mu \mathrm{m} \times 40 \\
\text { and } 56 \mathrm{~cm} ; 25 \mathrm{kV}, 25^{\circ} \mathrm{C}\end{array}$ & - & $\begin{array}{l}\text { Acid hydrolysis, filtration, clean- } \\
\text { up }(\mathrm{C} 18 \text { cartridge }) \text {, drying and } \\
\text { formic acid }(0.2 \%(\mathrm{v} / \mathrm{v})) \\
\text { dilution prior to } \mathrm{CE} \text { injection }\end{array}$ & $\begin{array}{l}\text { Evaluation of protein damage } \\
\text { throughout determination of } \\
\text { furosine in commercial soy- } \\
\text { based beverages (soy milk and } \\
\text { cow's milk supplemented with } \\
\text { soy isoflavones) }\end{array}$ & $\begin{array}{l}5.30 \mathrm{mg} / 100 \mathrm{~g} \\
\text { protein }^{\mathrm{a}}\end{array}$ & [29] \\
\hline & & $\begin{array}{l}{\mathrm{CZE}-\mathrm{MS}^{2}}^{2} \\
50 \mathrm{mM} \text { ammonium formate }(\mathrm{pH} \\
\text { 2.7); capillary, } 50 \mu \mathrm{m} \times 60 \mathrm{~cm} ; 25 \\
\mathrm{kV}, 30^{\circ} \mathrm{C}\end{array}$ & - & $\begin{array}{l}\text { Acid hydrolysis, filtration, } \\
\text { drying, dissolution with the } \\
\text { running buffer and re-filtration } \\
\text { before CE analysis }\end{array}$ & $\begin{array}{l}\text { Qualitative and quantitative } \\
\text { analysis of furosine in food } \\
\text { products (flours, pasta, milk, } \\
\text { and tigelle bread) }\end{array}$ & $0.07 \mathrm{mg} / \mathrm{L}$ & [30] \\
\hline & & $\begin{array}{l}\text { CZE-MS }^{2} \\
50 \mathrm{mM} \text { ammonium formate }(\mathrm{pH} \\
2.7) ; \text { capillary, } 50 \mu \mathrm{m} \times 60 \mathrm{~cm} \text {; } \\
25 \mathrm{KV}, 30^{\circ} \mathrm{C}\end{array}$ & - & $\begin{array}{l}\text { Acid hydrolysis, filtration, } \\
\text { drying, dissolution with the } \\
\text { running buffer and re-filtration } \\
\text { before CE analysis }\end{array}$ & $\begin{array}{l}\text { Quantification of furosine as } \\
\text { marker for the assessment of } \\
\text { thermal treatment of a cereal- } \\
\text { based model food (tigelle } \\
\text { bread) }\end{array}$ & - & [9] \\
\hline
\end{tabular}


Table 1. Continued

\begin{tabular}{|c|c|c|c|c|c|c|c|}
\hline Classification & Name (Abbr.) & $\begin{array}{l}\text { CE-mode/detection } \\
\text { Separation conditions }\end{array}$ & $\begin{array}{l}\text { Separation } \\
\text { from: }\end{array}$ & Sample treatment & Application & LOD* & Ref \\
\hline & $\begin{array}{l}\text { Domoic acid } \\
\text { (DA) }\end{array}$ & $\begin{array}{l}\text { pCEC-UV }(242 \mathrm{~nm}) \\
\text { ACN: } 5 \mathrm{mM} \text { Tris }(\mathrm{pH} 8.0)(60: 40 \mathrm{v} / \mathrm{v}) \text { at a } \\
\text { flow rate of } 0.05 \mathrm{~mL} / \mathrm{min} \text {; packed capillary } \\
\text { column, } 100 \mu \mathrm{m} \times 55 \mathrm{~cm} \text { (total length of } \\
\text { which } 20 \mathrm{~cm} \text { was packed with ODS } \\
\text { particles); }-13 \mathrm{kV} \text {; supplementary pressure } 7.2 \\
\text { MPa }\end{array}$ & - & $\begin{array}{l}\text { Extraction with methanol/water } \\
(1: 1 \mathrm{v} / \mathrm{v}) \text {, centrifugation, and } \\
\text { filtration prior to CEC analysis. }\end{array}$ & $\begin{array}{l}\text { Determination of DA in } \\
\text { shellfish tissues }\end{array}$ & $\begin{array}{l}0.5 \mu \mathrm{g} / \mathrm{mL} \\
\text { (equivalent to } 2 \mu \mathrm{g} \\
\mathrm{DA} / \mathrm{g}, \text { ww of } \\
\text { mussel tissue) }\end{array}$ & [11] \\
\hline & & $\begin{array}{l}\text { CZE-EIA-EC (Ed: }-0.35 \mathrm{~V} \text { ) } \\
1 \% \mathrm{PVP}+1 \mathrm{mM} \mathrm{H}_{2} \mathrm{O}_{2} \text { in } 10 \mathrm{mM} \mathrm{BR} \text { buffer } \\
(\mathrm{pH} 5.0) \text {; separation capillary, } 50 \mu \mathrm{m} \times 20 \\
\mathrm{~cm} \text {; reaction capillary, } 50 \mu \mathrm{m} \times 5 \mathrm{~cm} ; 15 \mathrm{kV}\end{array}$ & - & $\begin{array}{l}\text { Extraction with methanol/water } \\
(1: 1 \mathrm{v} / \mathrm{v}) \text {, centrifugation, } \\
\text { filtration. Then non } \\
\text { competitive inmunoreaction } \\
\text { between free domoic acid } \\
\text { antigen and (HRP)-labeled } \\
\text { antidomoic acid antibody, } \\
\text { incubation before CE analysis }\end{array}$ & $\begin{array}{l}\text { Quantitative analysis of } \\
\text { DA in contaminated } \\
\text { shellfish } \\
\text { samples(mussels, } \\
\text { oysters, clams and } \\
\text { scallops) }\end{array}$ & $0.02 \mathrm{ng} / \mathrm{mL}$ & [31] \\
\hline \multirow[t]{3}{*}{$\begin{array}{l}\text { Sulfur amino } \\
\text { acids }\end{array}$} & Taurine (Tau) & $\begin{array}{l}\text { CZE-LIF } \\
\left(\lambda_{\mathrm{ex}} \text { and } \lambda_{\mathrm{em}} \text { unspecified) }\right. \\
20 \mathrm{mM} \text { sodium phosphate }(\mathrm{pH} 11.8) \\
\text { capillary, } 75 \mu \mathrm{x} 40 \mathrm{~cm} ; 22 \mathrm{kV}, 23^{\circ} \mathrm{C}\end{array}$ & - & $\begin{array}{l}\text { Derivatization with FITC } \\
\text { (Energy drink was diluted 500- } \\
\text { fold before CE analysis) }\end{array}$ & $\begin{array}{l}\text { Quantification of Tau in } \\
\text { an energy drink and a } \\
\text { cow's milk }\end{array}$ & - & [32] \\
\hline & & $\begin{array}{l}\text { MEKC-C }{ }^{4} \mathrm{D}(450 \mathrm{kHz} ; 17 \mathrm{Vpp}) \\
40 \mathrm{mM} \text { CHES + } 15 \mathrm{mM} \mathrm{NaOH}+50 \mathrm{mM} \\
\text { SDS ( pH 9.36); capillary, } 50 \mu \mathrm{m} \text { x } 8 \mathrm{~cm} ; 5 \\
\mathrm{kV}\end{array}$ & Caffeine & $\begin{array}{l}\text { Sonication (to remove } \\
\text { dissolved gases) and dilution } \\
\text { (10-fold) with the BGE }\end{array}$ & $\begin{array}{l}\text { Simultaneous } \\
\text { determination of taurine } \\
\text { and caffeine in energy } \\
\text { drinks }\end{array}$ & $24 \mathrm{mg} / \mathrm{L}$ & [33] \\
\hline & & $\begin{array}{l}\text { MCE-Fluorescence } \\
\left(\lambda_{\mathrm{em}} 545 \text { and } 605 \mathrm{~nm}\right)\end{array}$ & - & $\begin{array}{l}\text { Buffer dissolution, } \\
\text { derivatization with NBD-Cl, } \\
\text { and dilution ( } 10 \text {-fold) in } \\
\text { separation buffer prior to CE } \\
\text { analysis }\end{array}$ & $\begin{array}{l}\text { Quantitative } \\
\text { determination of Tau } \\
\text { energy and sports drinks }\end{array}$ & $1 \times 10^{-6} \mathrm{M}$ & [34] \\
\hline
\end{tabular}


$50 \mathrm{mM}$ borate, $(\mathrm{pH} 9.3)$; glass microchip with

an orthogonal channel design $(10 \times 40 \mathrm{~mm})$

and a channel cross section of $20 \times 50 \mu \mathrm{m}$

Table 1. Continued

\begin{tabular}{|c|c|c|c|c|c|c|c|}
\hline Classification & Name (Abbr.) & $\begin{array}{l}\text { CE-mode/detection } \\
\text { Separation conditions }\end{array}$ & $\begin{array}{l}\text { Separation } \\
\text { from: }\end{array}$ & Sample treatment & Application & LOD* & Ref \\
\hline & \multirow[b]{2}{*}{ Homocysteine (Hcy) } & $\begin{array}{l}\text { MCE-LIF } \\
\left(\lambda_{\mathrm{ex}} 635 \mathrm{~nm} ; \lambda_{\mathrm{em}} 495 \mathrm{~nm}\right) \\
100 \mathrm{mM} \text { sodium borate (pH } \\
9.88) \text {; glass microchip with a } \\
\text { simple cross channel design; } \\
\text { separation channel, }(60 \mathrm{~mm} \times 25 \\
\mu \mathrm{mx} 70 \mu \mathrm{m} \text { (length } \mathrm{x} \text { depth } \mathrm{x} \\
\text { width)) } 45 \mathrm{~mm} \text { from injection to } \\
\text { the detector }\end{array}$ & $\begin{array}{l}\text { Lys, vitamin } \\
\mathrm{B}_{3}\end{array}$ & $\begin{array}{l}\text { Two-fold dilutions with } 40 \mathrm{mM} \\
\text { sodium borate, } \mathrm{pH} \text { adjustment } \\
\text { (pH 8.6), derivatization with } \mathrm{Cy} 5 \\
\text { and dilution with sample buffer } \\
(10 \mathrm{mM} \text { sodium borate, } \mathrm{pH} 9.88 \text { ) }\end{array}$ & $\begin{array}{l}\text { Simultaneous analysis of } \\
\text { amino acids (Tau and Lys) } \\
\text { and vitamin } B_{3} \text { in functional } \\
\text { drinks. }\end{array}$ & $0.50 \mathrm{nM}$ & {$[35]$} \\
\hline & & $\begin{array}{l}\text { CZE-LIF }(635 \mathrm{~nm}) \\
16 \mathrm{mM} \text { sodium citrate }(\mathrm{pH} 7.0)+ \\
60 \% \mathrm{v} / \mathrm{v} \text { ACN; capillary, } 75 \mu \mathrm{m} x \\
50 \mathrm{~cm} ; 22,5 \mathrm{kV}, 25^{\circ} \mathrm{C}\end{array}$ & $\begin{array}{l}\text { GSH, Cys, } \\
\gamma \text {-GluCys, } \\
\text { CysGly, and } \\
\text { NAC }\end{array}$ & $\begin{array}{l}\text { Extraction with PBS, } \\
\text { trichloroacetic acid, and EDTA } \\
\text { (added in order) centrifugation, } \\
\text { neutralization with sodium } \\
\text { hydroxide, and derivatization } \\
\text { with DMDSPAB-I before CE } \\
\text { analysis }\end{array}$ & $\begin{array}{l}\text { Determination of Hcy and } \\
\text { other thiols in cucumber and } \\
\text { tomato samples }\end{array}$ & $0.15 \mathrm{nM}$ & {$[36]$} \\
\hline & \multirow[t]{2}{*}{$\begin{array}{l}\text { S-alk(en)ylcysteine-S- } \\
\text { oxides }\end{array}$} & $\begin{array}{l}\text { CZE-UV }(350 \mathrm{~nm}) \\
20 \mathrm{mM} \text { sodium benzoate }+0.5 \\
\text { mM TTAB }(\mathrm{pH} 12.0) \text {; capillary, } \\
50 \mu \mathrm{m} \times 91.5 \mathrm{~cm} ;-30 \mathrm{kV}, 25^{\circ} \mathrm{C}\end{array}$ & $\begin{array}{l}\text { Separation } \\
\text { between } \\
\text { methiin and } \\
\text { alliin. }\end{array}$ & $\begin{array}{l}\text { Boiling and water extraction } \\
\text { (microwave), water dilution, and } \\
\text { filtration before CE analysis. }\end{array}$ & $\begin{array}{l}\text { Analyze of } \\
\text { S-alk(en)ylcysteine S-oxides } \\
\text { in allium and brassica } \\
\text { vegetables }\end{array}$ & - & {$[37]$} \\
\hline & & $\begin{array}{l}\text { MECK-indirect UV }(265 \mathrm{~nm}) \\
20 \mathrm{mM} \text { sodium borate }+20 \mathrm{mM} \\
\mathrm{SDS}+10 \%(\mathrm{v} / \mathrm{v}) \mathrm{MeOH}(\mathrm{pH} \\
9.2) ; \text { capillary, } 75 \mu \mathrm{m} \times 67 \mathrm{~cm} ; 20 \\
\mathrm{kV}, 25^{\circ} \mathrm{C}\end{array}$ & $\begin{array}{l}\text { Separation } \\
\text { between } \\
\text { Methiin, } \\
\text { Alliin, } \\
\text { Ethiin } \\
\text { Isoalliin } \\
\text { Propiin } \\
\end{array}$ & $\begin{array}{l}\text { Extraction with methanol/water } \\
(90: 10 \mathrm{v} / \mathrm{v})+10 \mathrm{mM} \mathrm{HCl} \text {, drying } \\
\text { until } 10-15 \mathrm{ml} \text { and dilution with } \\
20 \mathrm{mM} \text { sodium borate }(\mathrm{pH} 9.2) \text {, } \\
\text { filtration, and derivatization with } \\
\text { FMOC }\end{array}$ & $\begin{array}{l}\text { Simultaneous determination } \\
\text { of } S \text {-alk(en)ylcysteine- } S \text { - } \\
\text { oxidesin alliaceous } \\
\text { and cruciferous vegetables } \\
\text { (e.g. garlic, onion, leek, } \\
\text { chive, cabbage, radish, } \\
\text { cauliflower and broccoli) }\end{array}$ & $0.2 \mathrm{pmol}$ & {$[38]$} \\
\hline
\end{tabular}


Table 1. Continued

\begin{tabular}{|c|c|c|c|c|c|c|c|}
\hline Classification & Name (Abbr.) & $\begin{array}{l}\text { CE-mode/detection } \\
\text { Separation conditions }\end{array}$ & $\begin{array}{l}\text { Separation } \\
\text { from: }\end{array}$ & Sample treatment & Application & LOD* & Ref \\
\hline \multirow[t]{2}{*}{$\begin{array}{l}\text { Hydroxyl amino } \\
\text { acids }\end{array}$} & $\begin{array}{l}\text { Hydroxyproline } \\
\text { (Hyp) }\end{array}$ & $\begin{array}{l}\text { MEKC-UV }(214 \mathrm{~nm}) \\
0.05 \mathrm{M} \text { sodium borate }(\mathrm{pH} 9.3)+100 \\
\text { mM SDS; capillary, } 50 \mu \mathrm{m} \text { x } 50 \mathrm{~cm} \text {; } \\
12 \mathrm{kV}, 33^{\circ} \mathrm{C}\end{array}$ & Pro, Gly & $\begin{array}{l}\text { Acid digestion, filtration, } \mathrm{pH} \\
\text { adjustment (pH 10.0), solution in } \\
\text { sodium tetraborate, filtration, } \\
\text { derivatization with fluorescamine } \\
\text { and evaporation until } 30 \mu \mathrm{L}\end{array}$ & $\begin{array}{l}\text { Determination of Hyp as a } \\
\text { collagen content index in } \\
\text { meat products }\end{array}$ & - & {$[39]$} \\
\hline & & $\begin{array}{l}\text { MEKC-LIF } \\
\left(\lambda_{\mathrm{ex}} 473 \mathrm{~nm} ; \lambda_{\mathrm{em}} 520 \mathrm{~nm}\right) \\
25 \mathrm{mM} \text { sodium borate }+30 \mathrm{mM} \mathrm{SDS} \\
(\mathrm{pH} 9.7) ; \text { capillary, } 50 \mu \mathrm{m} \text { x } 40 \mathrm{~cm} \text {; } \\
20 \mathrm{kV}, 25^{\circ} \mathrm{C}\end{array}$ & - & $\begin{array}{l}\text { Hydrolysis, dilution (10000-fold), } \\
\text { and in-capillary derivatization } \\
\text { with NBD-F }\end{array}$ & $\begin{array}{l}\text { Determination of Hyp in milk } \\
\text { powder, liquid milk, milk } \\
\text { drink and soymilk powder }\end{array}$ & $1.6 \mathrm{ng} / \mathrm{mL}$ & {$[40]$} \\
\hline $\begin{array}{l}\text { Seleno } \\
\text { aminoacids }\end{array}$ & $\begin{array}{l}\text { Seleno- } \\
\text { methionine (Se- } \\
\text { Met) } \\
\text { Seleno-cysteine } \\
\text { (SeCys2) }\end{array}$ & $\begin{array}{l}\text { CZE-ICP-MS } \\
20 \mathrm{mM} \text { sodium phosphate }+10 \mathrm{mM} \\
\text { sodium borate }+0.2 \mathrm{mM} \mathrm{CTAB}(\mathrm{pH} \\
8.6) ; \text { capillary, } 75 \mu \mathrm{m} \times 80 \mathrm{~cm} ;-16 \\
\mathrm{kV}, 25^{\circ} \mathrm{C}\end{array}$ & $\begin{array}{l}\text { Separation } \\
\text { between } \\
\text { Se-Met } \\
\text { SeCys2 } \\
\text { Se(VI) } \\
\text { Se(IV) }\end{array}$ & $\begin{array}{l}\text { Enzyme-assisted extraction (using } \\
\text { protease and lipase), centrifugation, } \\
\text { filtration and dilution in water prior } \\
\text { to CE injection }\end{array}$ & $\begin{array}{l}\text { Simultaneous determination } \\
\text { of selenium species (Se(VI), } \\
\text { Se(IV), SeCys2 and SeMet) } \\
\text { in selenium-enriched rice }\end{array}$ & $\begin{array}{l}0.5 \mathrm{ng} / \mathrm{L} \mathrm{SeMet} \\
0.9 \mathrm{ng} / \mathrm{L} \mathrm{SeCys} 2\end{array}$ & [41] \\
\hline \multirow[t]{2}{*}{ Betaines } & Betaine & $\begin{array}{l}\text { CZE-indirect UV (214 nm) } \\
5 \mathrm{mM} \text { sulfanilamide }(\mathrm{pH} 2.2) \text {; } \\
\text { capillary, } 50 \mu \mathrm{m} \times 41.5 \mathrm{~cm} ; 25 \mathrm{kV} \text {, } \\
30^{\circ} \mathrm{C}\end{array}$ & Pro & $\begin{array}{l}\text { Extraction with } 80 \% \text { ethanol }(\mathrm{v} / \mathrm{v}) \\
\text { and filtration before CE analysis. }\end{array}$ & $\begin{array}{l}\text { Demonstrate the potential of } \\
\text { new probes for the } \\
\text { simultaneous determination } \\
\text { of betaine and Pro in spinach } \\
\text { and beetroot samples }\end{array}$ & $28.3 \mu \mathrm{M}$ & {$[42]$} \\
\hline & Trigonelline & $\begin{array}{l}\text { CZE-UV }(195 \mathrm{~nm}) \\
0.1 \mathrm{M} \text { ammonium formate }(\mathrm{pH} 2.0) \text {; } \\
\text { capillary, } 50 \mu \mathrm{m} \text { x } 66.5 \mathrm{~cm} ; 25 \mathrm{kV} \text {, } \\
35^{\circ} \mathrm{C}\end{array}$ & - & $\begin{array}{l}\text { Extraction with } \\
\text { methanol/chloroform }(2: 1 \mathrm{v} / \mathrm{v}) \text {, } \\
\text { centrifugation, drying and dilution } \\
\text { in ACN: water }(40: 60 \mathrm{v} / \mathrm{v}) \text {. } \\
\text { (Different volume of extracting } \\
\text { solvent (including wash steps) and } \\
\text { centrifugation parameters are used } \\
\text { in the sample treatment of seeds and } \\
\text { oils) }\end{array}$ & $\begin{array}{l}\text { Determination of trigonelline } \\
\text { in seeds and vegetables oils } \\
\text { as marker of adulterated olive } \\
\text { oils }\end{array}$ & $0.9 \mu \mathrm{M}$ & [43] \\
\hline
\end{tabular}


Table 1. Continued

\begin{tabular}{|c|c|c|c|c|c|c|c|}
\hline Classification & Name (Abbr.) & $\begin{array}{l}\text { CE-mode/detection } \\
\text { Separation conditions }\end{array}$ & $\begin{array}{l}\text { Separation } \\
\text { from: }\end{array}$ & Sample treatment & Application & LOD* & Ref \\
\hline & $\begin{array}{l}\text { trigonelline } \\
\text { glycine betaine } \\
\text { proline betaine } \\
\text { carnitines }\end{array}$ & $\begin{array}{l}\text { CZE-MS }{ }^{2} \\
0.1 \mathrm{M} \text { ammonium formate }(\mathrm{pH} \\
2.0) \text {; capillary, } 50 \mu \mathrm{m} \times 60 \mathrm{~cm} \text {; } \\
25 \mathrm{kV}, 25^{\circ} \mathrm{C}\end{array}$ & - & $\begin{array}{l}\text { Extraction with } \\
\text { methanol/chloroform }(2: 1 \mathrm{v} / \mathrm{v}) \text {, } \\
\text { centrifugation, drying, butanol } \\
\text { derivatization, evaporation and } \\
\text { dilution in ACN: water }(40: 60 \\
\mathrm{v} / \mathrm{v}) \text {. }\end{array}$ & $\begin{array}{l}\text { Potential of betaines as novel } \\
\text { markers of adulterations of } \\
\text { olive oils with seeds oils }\end{array}$ & $\begin{array}{l}0.050 \mathrm{ng} / \mathrm{g} \\
\text { (Carnitines, } \\
\text { trigonelline) } \\
0.075 \mathrm{ng} / \mathrm{g} \\
\text { (glycine and } \\
\text { proline betaine) }\end{array}$ & {$[8]$} \\
\hline & Carnitine (Carn) & $\begin{array}{l}\text { CZE-C }{ }^{4} \mathrm{D}(320 \mathrm{kHz} ; 280 \mathrm{Vpp}) \\
500 \mathrm{mM} \text { acetic acid }+0.05 \% \\
(\mathrm{v} / \mathrm{v}) \text { tween-20 (pH } 2.6) ; \\
\text { capillary, } 50 \mu \mathrm{m} \text { x } 32 \mathrm{~cm} ; 20 \mathrm{kV}\end{array}$ & - & $\begin{array}{l}\text { Dilution with } 500 \mathrm{mM} \text { acetic } \\
\text { acid, centrifugation and injection } \\
\text { in the } \mathrm{CE} \text { system }\end{array}$ & $\begin{array}{l}\text { Quantification of carnitine in } \\
\text { foodstuffs (fruit, juices, milk, } \\
\text { yogurt, cheese, red meat and } \\
\text { chicken meat) and food } \\
\text { supplements }\end{array}$ & $2.6 \mu \mathrm{M}$ & {$[44]$} \\
\hline Others & $\begin{array}{l}\text { N-phenylpropenoyl- } \\
\text { L-amino acids (NPA) }\end{array}$ & $\begin{array}{l}\text { CZE-UV }(325 \mathrm{~nm}) \\
\text { CE system 1: } 50 \mathrm{mM} \text { sodium } \\
\text { borate }(\mathrm{pH} 8.8), \text { capillary, } 70 \mu \mathrm{m} \\
\text { x } 70 \mathrm{~cm} ; 30 \mathrm{kV}, 27^{\circ} \mathrm{C} \\
\text { CE system 2: } 50 \mathrm{mM} \text { sodium } \\
\text { borate }(\mathrm{pH} 8.8), \text { capillary, } 50 \mu \mathrm{m} \\
\text { x } 50 \mathrm{~cm} ; 20 \mathrm{kV}, 27^{\circ} \mathrm{C}\end{array}$ & $\begin{array}{l}\text { Separation } \\
\text { between } \\
\text { Caff-Asp } \\
\text { pC-Asp } \\
\text { Caff-DOPA }\end{array}$ & $\begin{array}{l}\text { Cocoa beans and shells: deffating } \\
\text { (soxhlet), extraction with } \\
\text { acetone/water }(7: 3 \mathrm{v} / \mathrm{v}) \text {, } \\
\text { centrifugation, rotatory } \\
\text { evaporation, and centrifugation } \\
\text { prior to CE analysis } \\
\text { Flowers, leaves, husk, pulp, and } \\
\text { shells: same extraction protocol } \\
\text { without deffating }\end{array}$ & $\begin{array}{l}\text { Analysis of main NPA in } \\
\text { cocoa and cocoa products }\end{array}$ & - & {$[45]$} \\
\hline
\end{tabular}

*LODs units expressed as in the original work. These LODs are referred to the injected solutions of standard samples except for a) in which LODs is referred to the injected solutions of food samples. ${ }^{* *}$ Capillary dimension expressed as internal diameter $\mathrm{x}$ effective length (cm to the detector).

ACN, acetonitrile; Ala, alanine; Allo, allo-isoleucine; BR, Britton-Robinson buffer; Caff-Asp, N-[3',4'-dihydroxy-(E)-cinnamoyl]-L-aspartic acid; Caff-DOPA, N-[3',4'-dihydroxy-(E)cinnamoyl]-3-hydroxy-L-tyrosine; $\mathrm{C}^{4} \mathrm{D}$, capacitively coupled contactless conductivity; CE-EIA, capillary electrophoresis based enzyme immunoassay; CHES, 2-(N-cyclohexylamino)ethane sulfonic acid; Cit, citruline; CTAB, cetyltrimethylammonium bromide; Cy5, Sulfoindocyanine succinimidyl ester; Cys, cysteine; CysGly, cysteinylglycine; CZE, capillary zone electrophoresis; DMDSPAB-I, 1,7-dimethyl-3,5-distyryl-8-phenyl-(4'-iodoacetamido) difluoroboradiaza-s-indacene; EC, electrochemical; EDTA, ethylene diamine tetra acetic acid; EMMA, electrophoretically 
mediated microanalysis; FICT, fluorescein isothiocyanate; FMOC, 9-fluorenyl-methyloxycarbonyl chloride; GSH, glutathione; $\gamma$-GluCys, $\gamma$-glutamylcysteine; Gly, glycine; HRP, horseradish peroxidase; LIF, laser-induced fluorescence; Lys, lysine; 2- MCE, microchip capillary electrophoresis; ME, 2-mercaptoethanol; MEKC, micellar electrokinetic chromatography; MS², tandem mass spectrometry; NDB-Cl, 4-chloro-7-nitrobenzofurazan; ODS, octadecyl silica; OPA, o-phthaldialdehyde; PBS, phosphate buffer saline; pCEC, pressurized capillary electrochromatography; pCTyr, N-[4'-hydroxy-(E)-cinnamoyl]-L-tyrosine; pC-Asp, N-[4'-hydroxy-(E)-cinnamoyl]-L-aspartic acid; PDA, diode array detector; Pro, proline; PVP, polyvinylpyrolidone; Pyro, pyroglutamic acid; SDS, sodium dodecyl sulfate; Se, selenium; TCA, trichloroacetic acid; TTAB, tetradecyltrimethyl-ammonium bromide. 


\subsection{Aliphatic monoamino-monocarboxyl amino acids}

$\gamma$-Aminobutyric acid (GABA) is a non-protein amino acid whose structure contains one carboxylic group and one primary amino group attached to the gamma carbon atom. It is distributed throughout the nervous system and it is the main inhibitory neurotransmitter in the mammalian brain which helps to regulate neuron activity and keep nerve cells firing normally $[46,47]$. In addition, GABA has demonstrated to have potential to maintain the balance of blood pressure in individuals with hypertensive cardiovascular disease [48].

In the period of time covered by this review, different $\mathrm{CE}$ methodologies coupled to fluorescence o MS detection systems were developed for the determination of GABA in tea, commercial dietary supplements containing royal jelly and honey (see Table 1). The lack of a chromophore group in GABA makes essential to carry out a derivatization step to enhance fluorescence detection. Thus, an in-capillary labeled derivatization reaction was investigated with the aim of determining the content of GABA and alanine (Ala) in different tea samples. The in-capillary derivatization was based on the use of ophthalaldehyde/2-mercaptoethanol (OPA/2-Me) as labeling reagent. OPA reacts rapidly with primary amines in presence of a thiol co-reactant under alkaline conditions, and 2ME (neutral co-reactant) minimized the instability of the resulting fluorophores. Under the optimized derivatization and CZE conditions (30 mM sodium tetraborate ( $\mathrm{pH} 10.0)$ ), GABA and Ala were analyzed in only 14 min (including in-capillary derivatization and CZE separation) with LODs of 0.004 and $0.02 \mu \mathrm{M}$, respectively. Due to the existence of matrix interferences, a 1000-fold dilution of GABA-rich tea was needed before applying the developed methodology to the analysis of both amino acids in tea samples [22]. However, those tea samples with a low content of GABA could not be diluted. Then, to make possible the detection after dilution, an in-capillary sample stacking 
preconcentration was subsequently included in the CZE-fluorescence methodology (see Figure 1A) [23]. By using this strategy, both GABA and Ala were detected in jasmine green tea sample (which has a low content of GABA) as it is shown in Figure 1B. The use of sample stacking preconcentration allowed achieving LODs of 0.7 and $0.8 \mathrm{nM}$ for GABA and Ala, respectively. This implies a relevant enhancement of the LODs, from $\mu \mathrm{M}$ up to $\mathrm{nM}$ level, which clearly shows that the dilution of sample solution followed by a preconcentration strategy is an interesting option to carry out the sensitive CE detection of analytes in complex matrix samples. Moreover, both methodologies could be applied with quality control purposes since they enabled to monitor the GABA content in the GABA-rich tea manufacturing process. From an analytical point of view, these methodologies are of great interest since they include, in just one analysis, from an easy sample treatment (dilution to avoid interferences and derivatization to enhance fluorescence) to an in-capillary preconcentration strategy to improve sensitivity. Undoubtedly, both methodologies provide an easy, fast, and sensitive option for determining GABA in routine analysis.

The simultaneous determination of GABA and sixteen protein amino acids could also be performed without derivatization using a CZE-MS ${ }^{2}$ method which did not require a concentration step for sample preparation [24]. Using 1M formic acid ( $\mathrm{pH} 1.8$ ) as BGE and $50 \%(\mathrm{v} / \mathrm{v})$ methanol as sheath liquid, it was possible to carry out the identification and simultaneous determination of all the amino acids studied (see Table 1) in different dietary supplements containing royal jelly (tablets, capsules, powder, liquid drinks and raw materials) and honey samples. LOD for GABA was $0.84 \mu \mathrm{g} / \mathrm{g}$. Since the product analyzed contained specific proportions of amino acids, the developed methodology was useful to distinguish among different royal jelly products. Moreover, taking into account that royal jelly raw material has a different composition from honey, this CE-MS ${ }^{2}$ strategy 
along with the analysis of the content of trans-10-hydroxy-2-decenoic acid (the main fatty acid in royal jelly) could be employed to detect the intentionally use of honey instead of royal jelly.

\section{Figure 1.}
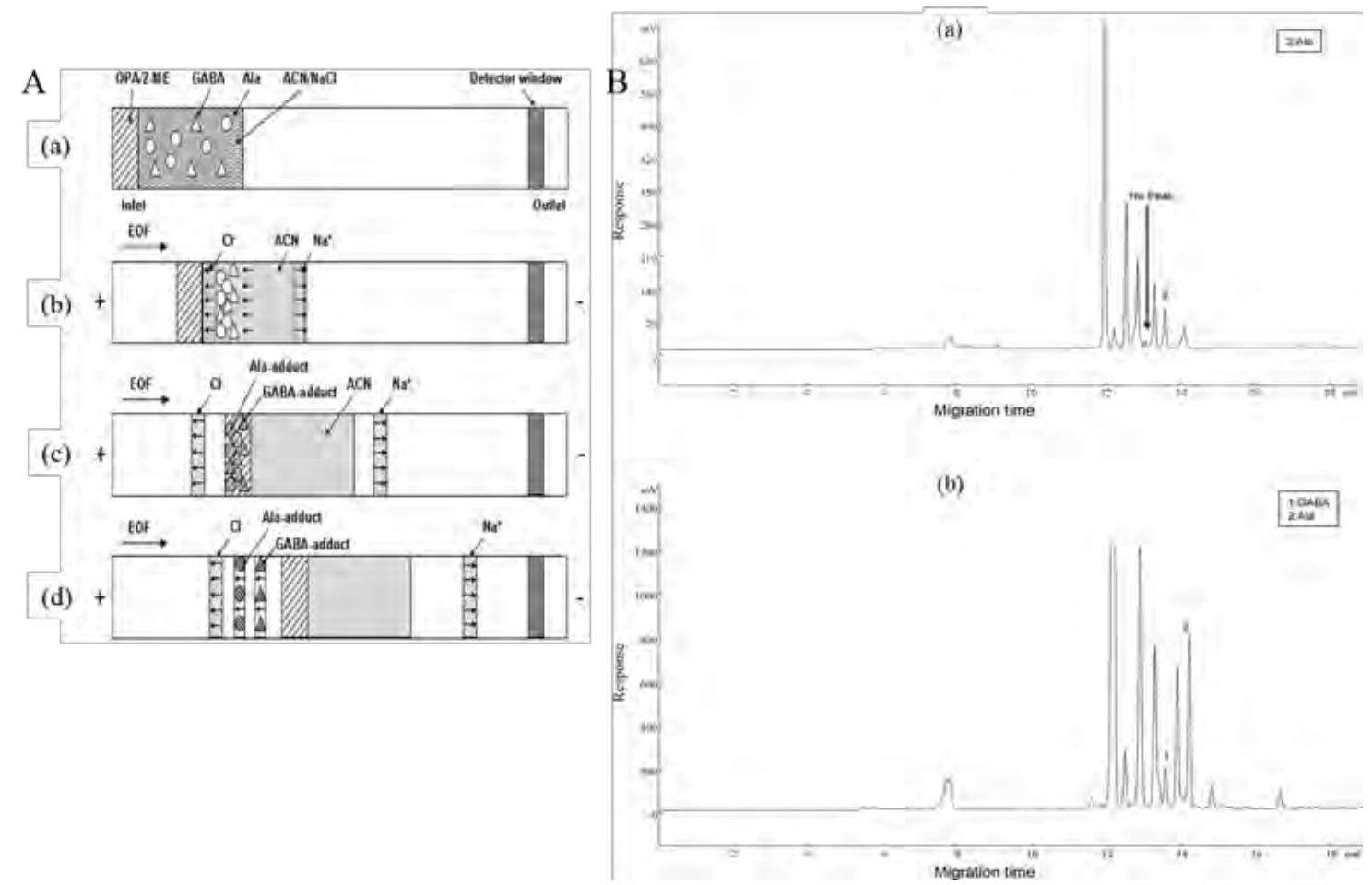

Fig. 1. A) Diagram of the in-capillary labeled derivatization and stacking in ACN/salt solution: (a) working sample solution and labeling agents were introduced successively to the anodic end of the capillary column; (b) labeled derivatization occurred in the stacking process of analytes; (c) stacking of the labeled derivatives; (d) CZE began once the stacked ions left the sample zone solution. B) Electropherograms of GABA and alanine in jasmine green tea sample: (a) undiluted; (b) via stacking. CZE conditions: BGE, $50 \mathrm{mM}$ sodium borate ( $\mathrm{pH}$ 10); uncoated fused-silica capillary, $50 \mu \mathrm{m}$ x $65 \mathrm{~cm}$; voltage; $21 \mathrm{kV}$; temperature, $23{ }^{\circ} \mathrm{C}$. Peaks: 1, GABA adduct; 2, Ala adduct. Reprinted with permission from [23]. Copyright (2010) American Chemical Society. 


\subsection{Aliphatic amino acids with nitrogen in the side chain}

Theanine (Thea), L-homoarginine (Har), $\beta$-N-methylamino-L-alanine (BMAA), and ornithine (Orn) are non protein amino acids containing nitrogen in their side chains.

Theanine, the chief non-protein amino acid in tea (representing up to $50 \%$ of the total amino acid content), is the main responsible of the taste of tea. It also has demonstrated to have an important role in different biological activities such as promoting relaxation, decreasing levels of serotonine and norepinephrine in brain, reducing blood pressure and enhancing anti-tumor activity [49]. A MEKC method using a BGE (pH 7.0) containing $10 \mathrm{mM}$ phosphate, $4 \mathrm{mM}$ sodium tetraborate, $45 \mathrm{mM}$ sodium dodecyl sulfate (SDS), and 0.5\% ethanol, and UV detection (205 and $266 \mathrm{~nm}$ ) was developed by Hsiao et al. [25] for the simultaneous determination of theanine, seven catechins, three xanthines, gallic acid, vitamin $\mathrm{C}$ and theaflavins in non-fermented, partially-fermented and fully-fermented tea samples. The successful separation of the studied compounds within 8 min enabled the application of the proposed method for the quality control of tea fermentation (in particular, the theanine content did not change significantly). Lately, Yan et al. [26] developed for the first time a high sensitive MEKC approach with LIF detection for the simultaneous analysis of 13 protein amino acids, theanine and GABA in five different tea leaves as shown in Figure 2. Brij 35 was used as surfactant and 4-chloro-7nitrobenzofurazan (NBD-Cl) was chosen as labeling reagent to avoid time-consuming sample cleanup procedure because it does not react with other water soluble extracts in tea. This MEKC-LIF methodology enabled the detection up to $0.5 \mathrm{ng} / \mathrm{mL}$ and $0.1 \mathrm{ng} / \mathrm{mL}$ of GABA and theanine respectively, and has proved to be an efficient method for determining amino acids in tea. The two MEKC methodologies developed during the time covered by this review have a great potential to carry out an exhaustive characterization 
of tea samples since both enable the determination of not only theanine but also of a broad variety of compounds that can be of high interest to evaluate manufacturing processes.

\section{Figure 2.}
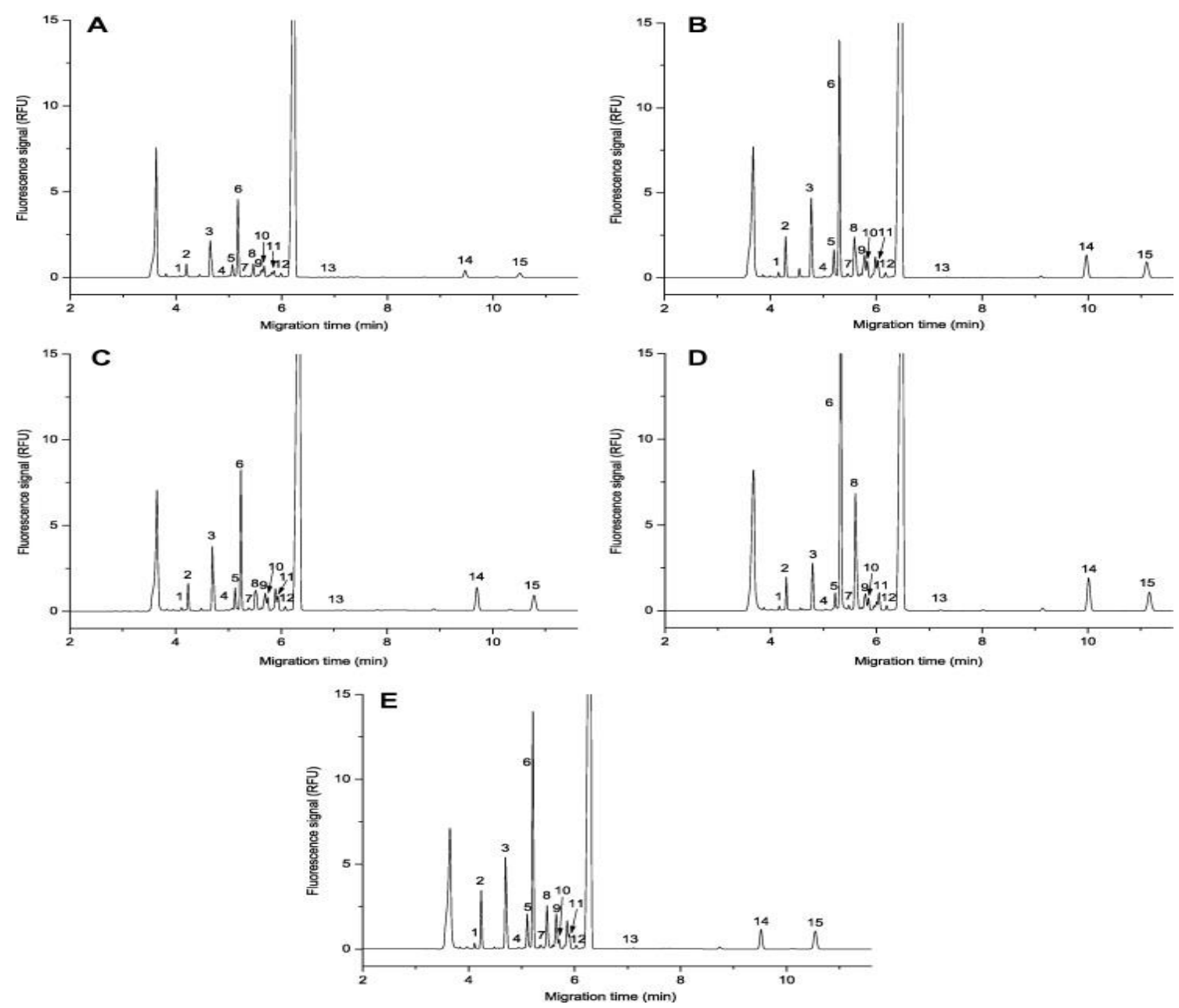

Fig. 2. MEKC electropherograms of amino acids in different tea varieties. (A) black, (B) jasmine, (C) green, (D) maofeng, and (E) biluochun. Derivatization conditions: $40 \mathrm{mM}$ NBD-Cl, $30 \mathrm{mM}$ sodium borate $(\mathrm{pH} 8.5)$, reaction time of $30 \mathrm{~min}$ at $60{ }^{\circ} \mathrm{C}$. Separation conditions: BGE, $20 \mathrm{mM}$ sodium borate (pH 8.5) with $20 \mathrm{mM}$ Brij 35 and $10 \%$ acetonitrile (v/v); voltage, $20 \mathrm{kV}$; temperature, $25^{\circ} \mathrm{C}$. Peak 1, Lys; 2, Phe; 3, Leu; 4, Met; 5, Val; 6, Thea; 7, His; 8, GABA; 9, Thr; 10, Ala; 11, Ser; 12, Gly; 13, Cys; 14, Glu; 15, Asp. Reprinted from [26], copyright (2014) with permission from Elsevier. 
L-Homoarginine (Har) and $\beta$-diaminopropionic acid ( $\beta$-ODAP) are the main non protein amino acids in grass pea seeds. The impact of Har in humans and animal diets has given rise to contrasting opinions. A positive effect is considered due to its conversion into lysine and its potential to modulate $\beta$-ODAP toxicity $[50,51]$. However, other studies suggested that Har modulates the biosynthesis of NO decreasing the excitation of neuronal receptors, and its presence in gene activator-repressor histones could be a cause of different cancer types $[52,53]$. The variation of the Har amount among grass pea genotypes cultivated in different Italian regions (with different soil properties and climatic conditions) in two consecutive years was investigated by using a CZE method [27]. The Har analysis was accomplished with UV detection at $200 \mathrm{~nm}$ using a $18.5 \mathrm{mM}$ sodium borate $(\mathrm{pH}$ 9.2) containing $10 \mathrm{mM}$ sodium sulfate as running buffer. This methodology was successfully applied to obtain information about the variation of Har in different grass pea genotypes observing that in all cases there was a trend towards increasing Har content in the second season being Har contents always higher in one of the regions investigated (Guardia Perticara). Moreover, the variation of grain yield did not affect the Har storage.

$\beta$-N-methylamino-L-alanine (BMAA) is a neurotoxic non-protein amino acid involved in the Amyotrophic Lateral Sclerosis which has been found in strains of cyanobacteria in fresh water and marine environment $[54,55]$. Due to its toxicological effect its quantitation in cyanobacteria is of great interest. A CZE method based on the use of $5 \mathrm{mM}$ sodium borate ( $\mathrm{pH} 9.0$ ) as BGE and UV detection at $192 \mathrm{~nm}$ was developed by Baptista et al. [28] enabling the separation of BMMA from its isomer 2,4diaminobutyric acid (DBA). Eighteen strains of lyophilized estuarine cyanobacteria were analyzed employing the proposed method after a sequential BMMA extraction using trichloroacetic acid (TCA) and hydrochloric acid. Hydrochloric acid extraction was more 
effective than TCA extraction (except for one type of cyanobacteria which is called Nostoc sp.).

An interesting CE-MS ${ }^{2}$ methodology was developed enabling the determination of non-protein amino acids in vegetable oils [7]. The simultaneous separation of ornithine, $\beta$-alanine, GABA, alloisoleucine, citrulline, and pyroglutamic acid, previously derivatized with butanol, was achieved in only 15 min with a $0.1 \mathrm{M}$ formic acid buffer ( $\mathrm{pH}$ 2.0). LODs between 0.04 and $0.19 \mathrm{ng} / \mathrm{g}$ were achieved when a normal stacking was used as preconcentration technique. Under these conditions, different vegetable oils (soybean, sunflower, corn and extra virgin olive oils) were analyzed in order to identify the selected non-protein amino acids. $\beta$-alanine, GABA, and pyroglutamic acid were detected in all the vegetable oils analyzed, whereas ornithine and alloisoleucine were only detected in soybean, corn and sunflower oils, and citrulline was not detected in any sample. Bearing these results in mind, and corroborating the presence of ornithine and alloisoleucine in seed oils but not in olive oils by $\mathrm{MS}^{2}$ experiments, these two non-protein amino acids were proposed as novel markers for the detection of olive oil adulterations with sunflower, soybean and corn seed oils.

\subsection{Heterocycle amino acids}

Furosine and domoic acid are non protein amino acids characterized by the presence of a heterocycle group in the side chain and were analyzed by CE in the period of time covered by this review as it can be seen in Table 1 .

Furosine is originated in the reaction between lysine and reducing carbohydrates and is one of the Maillard reaction products most widely used as markers of the nutritional quality of foods. Its presence and amount in foods is related to the Maillard reaction so that it has demonstrated to be a reliable indicator of thermal treatment in many food 
products. In the last eight years furosine was analyzed by $\mathrm{CE}$ with the aim of evaluating protein damage in commercial soy-based beverages [29], to study the effect of milling, drying or thermal processes in different food products (flours, pasta, milk and tigelle bread) [30] or to investigate the cooking effect of different ovens on a cereal-based model food (tigelle bread) [9]. All the strategies developed with these purposes are based on simple sample treatments and fast CE analysis (around $4 \mathrm{~min}$ ), both conditions of high interest for setting up an analytical methodology in food control laboratories.

To evaluate the protein quality of soy beverages, furosine was determined by CZE in different types of soy milk or cow's milk supplemented with soy isoflavones. A $50 \mathrm{mM}$ sodium phosphate buffer ( $\mathrm{pH}$ 7.0) was employed as BGE together with UV detection. The results were comparable with those obtained by an HPLC method. Even though HPLC proved to be slightly more sensitive than CZE (LODs of 1.30 and $5.30 \mathrm{mg} / 100 \mathrm{~g}$ of protein for HPLC and CZE, respectively), CZE was less time consuming (4 min versus $20 \mathrm{~min}$ ) and caused less contamination, which showed the feasibility of the proposed CZE method [29].

The influence of different thermal processes on the quality of several food products was also investigated through the determination of furosine by CZE coupled to MS detection. Bignardi et al. [30] optimized different experimental conditions, such as capillary length, BGE concentration and $\mathrm{pH}$, and applied voltage to establish a fast and reliable CZE-MS ${ }^{2}$ for determining the furosine content in flours, pasta, milk and tigelle bread (treated under different milling, drying or thermal processes). Under the optimized conditions (see Table 1), furosine was analyzed in 4 min achieving a LOD of $0.07 \mathrm{mg} / \mathrm{L}$. Afterwards, these authors employed the same CE-MS ${ }^{2}$ method to evaluate the effect of different cooking treatments (two different ovens, modifying time and temperature) on tigelle bread through the determination of the furosine amount (along with the measure 
of maltose: maltulose ratio or colour index) [9]. The negative correlation between the furosine amount and the different cooking processes, suggested that under the cooking parameters tested furosine was transformed in other molecules.

Domoic acid (DA) is a crystalline water soluble kainoid amino acid which has neurotoxic effects. The consumption of shellfish containing high concentration of DA could be responsible of the amnesic shellfish poisoning (ASP) syndrome that produces abdominal cramps, vomits, disorientation and memory loss [56]. Despite the great evolution of CEC as separation technique, its potential in the analysis of non-protein amino acids in foods has not yet been achieved. This fact can be clearly observed in Table 1 since the only CEC methodology proposed in the period of time covered by this review to carry out the achiral determination of non-protein amino acids was applied to the rapid quantitation of DA in shellfish tissue extracts [11].To avoid practical problems related with bubble formation and column drying, an additional pressure was applied to the column inlet. Thus, a pressurized CEC-UV (pCEC-UV) method based on the use of a packed capillary column with octadecyl silica (ODS) particles, an isocratic separation (flow rate of $0.05 \mathrm{~mL} / \mathrm{min}$ ), and a supplementary pressure of $7.2 \mathrm{MPa}$, was developed to separate DA in shellfish matrices within 6 min achieving a LOD of $0.5 \mu \mathrm{g} / \mathrm{mL}$. A second CE methodology based on enzyme immunoassay and electrochemical detection was also proposed to carry out the quantitative analysis of DA in shellfish samples [31]. This method, based on noncompetitive immunoreaction between DA antigen (Ag) and horseradish peroxidase (HRP)-labeled antidomoic acid antibody tracer ( $\left.\mathrm{Ab}^{*}\right)$ in liquid phase, was able to separate the immmunocomplex $\left(\mathrm{Ab}^{*}-\mathrm{Ag}\right)$ and unbound $\left(\mathrm{Ag}^{*}\right)$ in 4 min. The electrochemical detection was accomplished measuring amperometrically the enzymatic product obtained from the oxidation of $o$-aminophenol (OAP) with hydrogen peroxide. An LOD of $0.02 \mathrm{ng} / \mathrm{ml}$ was obtained enabling this approach to improve around 
16 times the sensitivity reached by a commercial ELISA check kit. Although the proposed methodology provides a sensitive approach for the trace determination of DA in shellfish samples, the need to carry out a noncompetitive immune reaction between DA antigen and (HRP)-labeled antidomoic acid antibody as well as the use of an electrochemical detector can difficult its implementation in routine food laboratories.

\subsection{Sulfur amino acids.}

Taurine (Tau), Homocysteine (Hcy) and a group of S-alk(en)ylcysteine-S-oxides (namely, methiin, ethiin, isoallin, propiin and butiin) were the sulfur-containing non protein amino acids analyzed by $\mathrm{CE}$ in the reviewed period.

Taurine is a semi-essential amino acid that plays an important role in a variety of physiological functions (antioxidation, neuromodulation, etc), pharmacological properties (liver protection, low blood pressure, etc), and pathological effects (change of taurine's levels in tissues and physiological fluids has a close relationship with different diseases such as Alzheimer, cardiovascular diseases or epilepsy, among others) [32]. Nowadays, the high consumption of energy and sport drinks makes that the normal daily uptake of taurine (one of the main components of these drinks) could be exceeded which can have undesirable effects. Therefore, reliable analytical methodologies are needed to determine taurine in foods from a quality control viewpoint. Bearing in mind this purpose, different strategies based on CZE, MEKC and microchip capillary electrophoresis (MCE) have been proposed. For instance, a CZE method with LIF detection was developed by Zinello et al. [32] to determine taurine in food and clinical samples (energy drinks and cow's milk). The use of a high incubation temperature $\left(100^{\circ} \mathrm{C}\right)$ enabled to reduce the reaction time between fluorescein isothiocyanate (FITC) and taurine from 6-14 h to 20 min. After optimization of different electrophoretic variables (buffer concentration, $\mathrm{pH}$, 
and temperature), the use of $20 \mathrm{mM}$ sodium phosphate at $\mathrm{pH} \mathrm{11.8,} \mathrm{a} \mathrm{temperature} \mathrm{of} 23$ ${ }^{\circ} \mathrm{C}$, and a separation voltage of $22 \mathrm{kV}$ allowed the analysis of taurine in less than $12 \mathrm{~min}$. Different energy drinks were analyzed observing taurine contents in good agreement with the labeled ones. MEKC was also employed to determine taurine in energy drinks. In this case, the aim was to determine the caffeine and taurine contents (the major components) simultaneously in energy drinks, using a dual detection system in a short capillary (10.5 $\mathrm{cm}$ ) employing a laboratory-home-made instrument [33]. Caffeine was detected by UV detection, whereas contactless conductivity detection $\left(C^{4} D\right)$ was employed for determining taurine since it does not absorb in the UV/Vis region. Using a simple sample treatment and a $40 \mathrm{mM}$ CHES buffer containing $15 \mathrm{mM}$ sodium hydroxide and $50 \mathrm{mM}$ SDS, taurine and caffeine analysis was accomplished in only $1 \mathrm{~min}$. This method has many outstanding features including the elimination of derivatization step and the possibility to carry out a fast separation of the two main compounds in energy drinks.

Regarding MCE, it is one of the most relevant applications of micro-fluidics which offers some advantages such as miniaturization, short analysis times, and low solvent and sample consumption. From its introduction, MCE has experienced a substantial growth so that it is being considered as a new trend capable of solving a variety of problems in food analysis. In the period of time covered by this review, two different MCE methodologies were developed to determine taurine in beverages with fluorescence and LIF detection. On the one hand, using a simple sample pretreatment (just two dilution steps) and 4-chloro-7-nitro-1,2,3-benzofurazan (NBD-Cl) as labeling reagent, it was possible to quantify taurine in energy and sports drinks in only $12 \mathrm{~s}$ reaching a LOD of 1 $\mathrm{x} 10^{-6} \mathrm{M}[34]$. On the other hand, MCE with LIF detection was recently applied to the sensitive analysis of taurine, lysine, and $\mathrm{B}_{3}$ vitamin derivatized with sulfoindocyanine succinimidyl ester (Cy5) in functional drinks [35]. Even though LIF has shown to be a 
potent detection method in sample analysis, the MCE-LIF sensitivity is sometimes not enough in sample analysis because of the low sample volume and short optical pathlength of the microchannels. For this reason, the development of on-line preconcentration methods able to enhance the sensitivity of MCE is relevant. With this aim, an on-line preconcentration approach combining field-amplified stacking (FASS) and reversed-field stacking was developed for the first time to achieve a sensitive analysis. The schematic mechanism of this strategy is shown in Figure 3A. The electrophoretic profiles obtained for the different concentration steps (see Figure 3B) demonstrated that both steps were crucial to achieve enhancement factors of 165-, 285- and 236-fold compared to the signal intensity without concentration. Under optimal conditions, taurine, lysine and $\mathrm{B}_{3}$ vitamin were focused and separated within 4 min achieving LODs at the nM level. The MCE-LIF methodology was successfully applied to the analysis of these ingredients in eight different functional drinks samples with a satisfactory recovery (see Figure 3C) and results were in good agreement with those listed in the label of the products.

\section{Figure 3.}

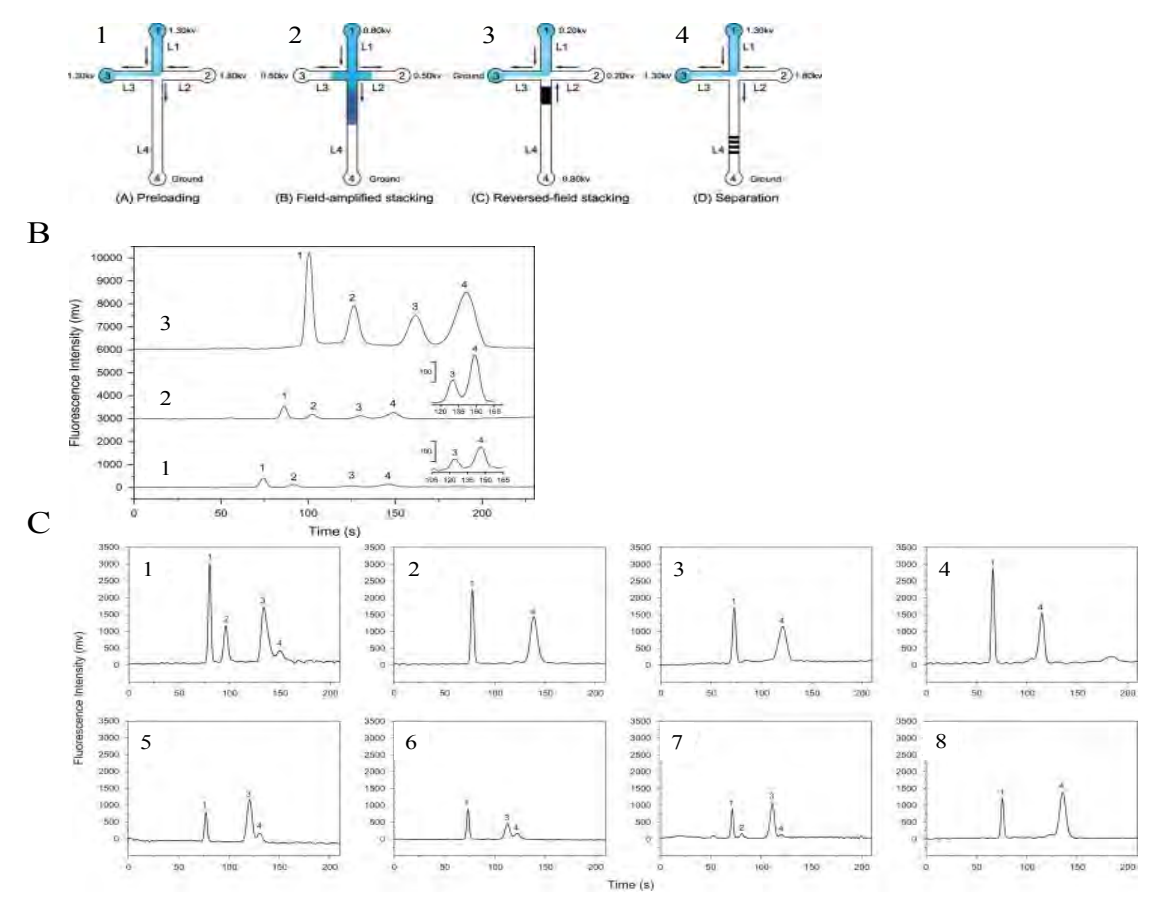


Fig. 3. A) Diagram of the MCE sample loading, on line preconcentration, and separation of nutritious compounds: (1) preloading, (2) FASS, (3) reversed-field stacking, and (4) separation. The dark blue zone represents the concentrated sample by FASS before using reversed-field stacking technique, the black zone represents the area of the concentrated sample after reversed-field stacking, the light blue zone represents the sample matrix, and the clear zone represents the running buffer. B) Signal enhancement of the multiple concentration: (1) signal intensity without concentration (buffer, $100 \mathrm{mM}$ borate $(\mathrm{pH}$ 9.88), sample diluted with the buffer, sample injection time, $2 \mathrm{~s}$ ), (2) signal intensity with FASS (sample prepared in a 10-fold-diluted buffer, sample injection time, 2 s), (3) signal intensity with a combination of FASS and reversed-field stacking (sample injection time, $10 \mathrm{~s}$; reversed-polarity time, $8 \mathrm{~s}$ ). The concentrations of Lys, Tau, and NA in (1) were $0.6,0.9$, and $0.6 \mu \mathrm{M}$, respectively. The sample concentrations in (2) and (3) were 1/10 of that in (1). Peak 1, excess of Cy5; 2, Lys; 3, Tau; and 4, NA. C) MCE electropherograms of eight different Cy5-labeled functional drink samples after dilution. Dilution fold: (1), 32000; (2), 1600; (3), 2000; (4), 2000; (5), 32000; (6), 64000; (7), 320000; and F8, 2000. Reprinted from [35], copyright (2015) with permission from Elsevier.

Homocysteine (Hcy) is a non-protein thiol amino acid (contains a sulfhydryl group in its structure) formed during methionine's metabolism. Thiols play an important role in abiotic and biotic stress resistance involved in the detoxification of xenobiotics in many organisms and they have nutritional value for humans when they are present in fruits and vegetables [57,58]. To achieve thiol determination by CZE with LIF detection, a fluorescent labeling reagent is always required because these compounds do not have detectable fluorescence. Taking this into account, Zhang et al. [36] developed a CZE-LIF methodology to determine Hcy along with other thiol compounds (cysteine, cysteinylglycine, $\gamma$-glutamylcysteine, glutathione, and $\mathrm{N}$-acetylcysteine) in cucumber and 
tomato samples using a new near-infrared fluorescent probe (namely 1,7-dimethyl-3,5distyryl-8-phenyl-(4'-iodoacetamide)difluoroboradiaza-s-indacene (DMDSPAB-I)) as labeling reagent. By using the appropriate derivatization protocol $\left(45^{\circ} \mathrm{C}\right.$ for $\left.25 \mathrm{~min}\right)$, and the best separation conditions (16 mM sodium citrate at $\mathrm{pH} 7.0$ containing $60 \%(\mathrm{v} / \mathrm{v})$ ACN), the studied thiols were analyzed within 14 min. The LOD obtained for Hcy with the proposed methodology was $0.15 \mathrm{nM}$. The authors proposed the method as a good alternative to investigate the biological function of low molecular weight thiols at trace levels.

S-Alk(en)ylcysteine-S-oxides are non protein amino acids which appear as secondary metabolites in plants, fungi and algae and are precursors of a great variety of sensory-active and healthy compounds of Allium (onion, garlic, leek, etc) and Brassica vegetables (broccoli, cabbage, cauliflower, etc) [38]. Hideki et al. [37] developed a simple and rapid CZE method to analyze methiin and alliin in Allium and Brassica vegetables using indirect $U V$ detection (at $350 \mathrm{~nm}$ ) and $20 \mathrm{mM}$ sodium benzoate containing $0.5 \mathrm{mM}$ tetradecyltrimethyl-ammonium bromide (TTAB) as BGE. The use of a sample treatment based on boiling, extraction, dilution and filtration, (without derivatization), gave rise to a total analysis time for methiin and alliin in vegetables less than $25 \mathrm{~min}$ per sample. An interesting advantage of this CZE methodology was the possibility to detect pyruvate which is a useful marker of unsuccessful sample preparations (the peak for pyruvate appeared instead of methiin and alliin peaks when the samples were extracted without boiling (blanching)).

Determination of the whole range of S-Alk(en)ylcysteine-S-oxides in alliaceous and cruciferous vegetables (fresh vegetables and garlic made products) was also carried out by MEKC with UV detection (previous derivatization with FMOC) [38]. Among the compounds investigated, isoalliin determination generated a special interest because it is 
the responsible of the pungency of onion and the undesirable decoloration of garlic [59]. The developed MEKC methodology, based on the use of $20 \mathrm{mM}$ sodium borate containing $20 \mathrm{mM}$ SDS and $10 \%$ methanol as running buffer, enabled the simultaneous separation of S-Alk(en)ylcysteine-S-oxides (methiin, alliin, isoalliin, propiin, and ethiin) within 20 min and a LOD at the pmol level. Alliin was found only in garlic whereas isoalliin was the main compound in other Allium species (such as onion, leek, chive and shallot). On the other hand, methiin was the only compound contained in plants from the Cruciferae family (occasionally along with traces of ethiin) [38].

\subsection{Hydroxyl amino acids.}

Hydroxyproline (Hyp) is the only hydroxyl amino acid analyzed in food samples by $\mathrm{CE}$ in the period of time covered by this review. It is formed by hydroxylation of proline and it is the most abundant component in collagen so that it can be used as marker of collagen content index (collagen is often added in its natural form or as hydrolysates in some products as a protein source being its levels regulated due to collagen effects on food quality). Two MEKC methods were developed to determine Hyp content in different matrix (meat and milk products) employing UV or LIF detection. To carry out the determination of Hyp (as collagen content index) with UV detection, the MEKC method was based on the use of fluorescamine as labeling reagent and $0.05 \mathrm{M}$ sodium borate containing $100 \mathrm{mM}$ SDS as running buffer [39]. Under these conditions, Hyp was clearly separated not only from other amino acids (Pro and Gly) present in collagen but also from other compounds present in meat samples. Since the results obtained using the developed MEKC-UV method were in agreement with the AOAC official colorimetric method, it can be considered as an alternative for Hyp analysis in meat products. Regarding the MEKC method with LIF detection, it was developed with the aim of providing a rapid 
and sensitive determination of Hyp in different dairy products for food quality assurance [40]. An in-capillary derivatization with 4-fluoro-7-nitro-2,1,3-benzoxadiazole (NBD-F) and a $25 \mathrm{mM}$ sodium borate buffer containing $30 \mathrm{mM}$ SDS as running buffer were employed. Derivatization and separation was completed in only $7 \mathrm{~min}$ and the LOD for Hyp was $1.6 \mathrm{ng} / \mathrm{mL}$, both remarkable features enabling to consider the proposed methodology as an alternative for the quality control of dairy products. In addition, these analytical features are relevant advantages compared with other chromatographic alternatives (HPLC, GC or CE), either with LIF or other types of detector, described in the literature to perform the determination of Hyp. In fact this methodology provided comparable or higher sensitivity and decreased the analysis time thanks to the use of an in-capillary derivatization which also allows a full automatization.

\subsection{Seleno amino acids.}

Selenium is an essential trace element for human health whose deficiency causes serious nutritional and health problems. An effective way for providing selenium is through the selenium-enriched foods intake. To carry out the nutritional and toxic evaluation of selenium compounds (Se (IV), Se (VI) and the non-protein amino acids selenocysteine ( $\left.\mathrm{SeCys}_{2}\right)$ and selenomethionine (SeMet)) in nutritional food supplements, Zhao et al. [41] developed a CZE-inductively coupled plasma MS (CZE-ICP-MS) methodology. As it can be seen in Table 1, sample treatment included an enzyme-assisted extraction approach to extract all selenium species and the CZE separation was accomplished using $20 \mathrm{mM}$ sodium phosphate, $10 \mathrm{mM}$ sodium borate and $0.2 \mathrm{mM}$ cetyltrimethylammonium bromide (CTBA) as separation buffer ( $\mathrm{pH}$ 8.6). LODs of 0.5 $\mathrm{ng} / \mathrm{L}$ and $0.9 \mathrm{ng} / \mathrm{L}$ for SeMet and $\mathrm{SeCys}_{2}$ respectively, and recoveries in the range 90-103 $\%$ were achieved. Figure 4 shows the electropherograms obtained for a selenium- 
enriched rice and the same sample spiked with the selenium species studied. As Figure 4 shows, only the non-protein amino acid SeMet was detected in selenium-enriched rice in the range of $0.136-0.143 \mathrm{mg} \mathrm{Se} / \mathrm{g}$ dried weight.

\section{Figure 4.}
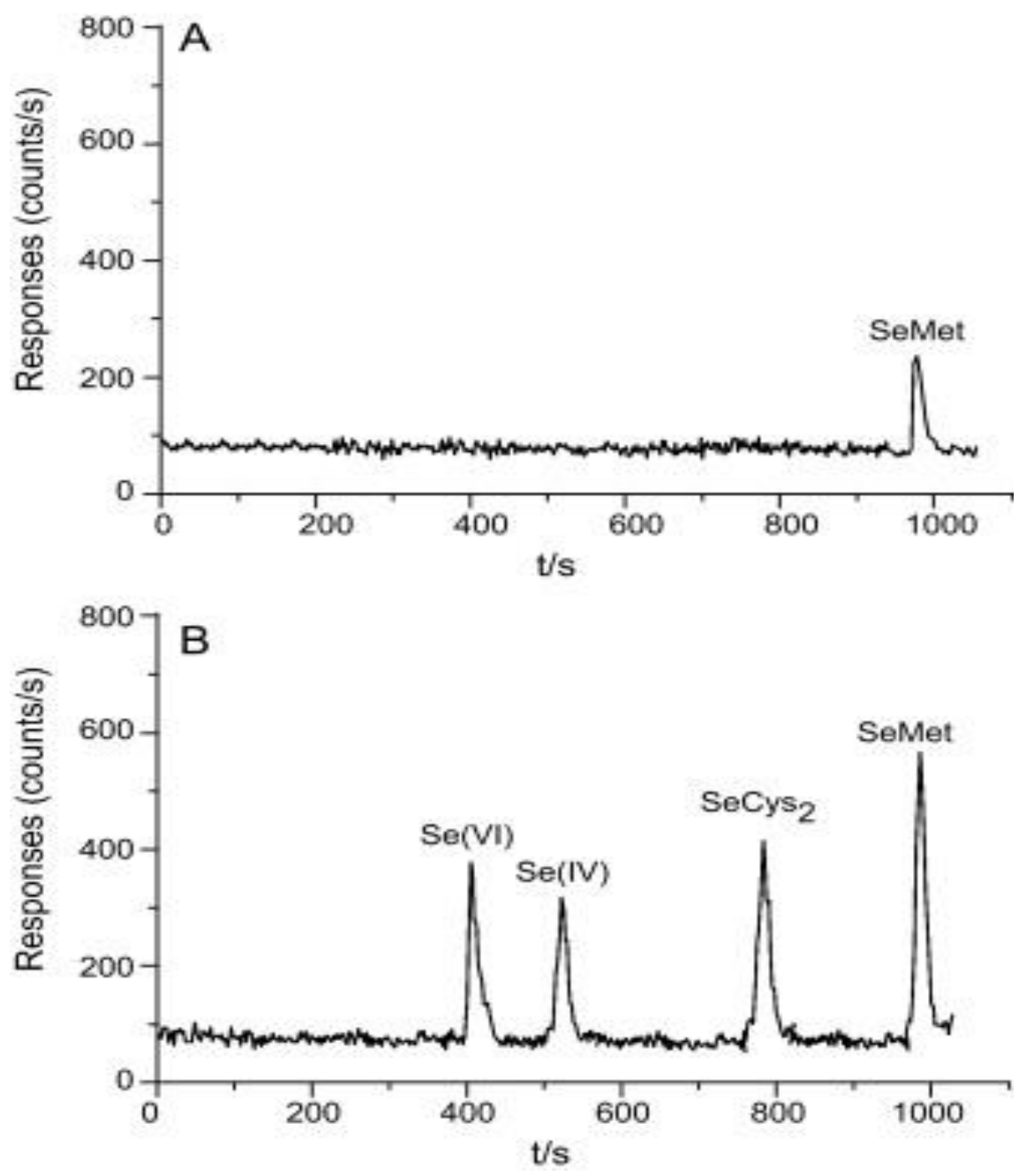

Fig. 4. The electropherograms of $\mathrm{Se}(\mathrm{VI}), \mathrm{Se}(\mathrm{IV}), \mathrm{SeCys}_{2}$ and SeMet under the optimal CZE-ICP-MS conditions: BGE, $20 \mathrm{mM}$ sodium phosphate- $10 \mathrm{mM}$ sodium borate- 0.2 mM CTAB (pH 8.6); uncoated fused-silica capillary, $75 \mu \mathrm{m}$ x $80 \mathrm{~cm}$; voltage; $-16 \mathrm{kV}$; temperature, $25^{\circ} \mathrm{C}$. (A) selenium-enriched rice; (B) selenium enriched rice spiked with $1.0 \mu \mathrm{g} / \mathrm{g}$ of Se(VI), Se(IV), SeCys2 and SeMet. Reprinted from [41], copyright (2011) with permission from Elsevier. 


\subsection{Betaines.}

Betaines are zwitterionic non protein amino acids which possess a quaternary ammonium group and a carboxylic group in their structure. They play a key role in many plants as osmoregulating compounds that help to tolerate environmental stress [60]. Betaine, trigonelline, glycine betaine, proline betaine, and carnitine have been the betaines analyzed by $\mathrm{CE}$ in different food samples during the time covered by this review.

The simultaneous determination of betaine and the protein amino acid proline was accomplished using a CZE methodology with indirect UV detection [42]. Among a variety of different probes (imidazole, creatinine, 4-aminopyridine, 4-aminobenzoic acid, sulfanilamide, etc), sulfanilamide demonstrated to be the most appropriate for the indirect detection of the studied compounds due to its slow mobility and good molar absorptivity. Under the optimal experimental conditions (see Table 1) and using $5 \mathrm{mM}$ sulfanilamide, it was possible to achieve a LOD of $28.3 \mu \mathrm{M}$ for betaine. The applicability of this methodology was demonstrated with the identification and quantification of betaine in extracts obtained from spinach and beetroot samples.

Trigonelline belongs to pyridine betaines group. It has demonstrated to have different health-promoting effects such as hypocholesterolemic, antitumor, or antimigraine, among others [61]. The determination of trigonelline in seeds and vegetables oils by CZE with UV detection (195 nm) enabled to propose this compound as a novel marker for the detection of adulterations in olive oils [43]. Under the experimental conditions detailed in Table $\mathbf{1}$ and using an in-capillary normal stacking as sample preconcentration strategy, trigonelline was detected in both soy and sunflower seeds (and their oils) but not in olives or olives oils at least above the LOD of the developed method (LOD up to $0.9 \mu \mathrm{M}$ ) [43]. Taking into account the limitation of this 
CE-UV methodology to detect trigonelline in olives or olive oils, a CZE-MS ${ }^{2}$ strategy was further carried out with the aim of detecting olive oil adulterations with seed oils through the simultaneous analysis of trigonelline and other betaines, such as proline betaine, glycine betaine (see Figure 5A) [8]. Following the same sample treatment described for the determination of ornithine in olive and seed oils [7] and using a derivatization with butanol to improve not only the analytical sensitivity but also the selectivity (by improving mass differentiation among analytes) the separation was achieved within 10 min using a $0.1 \mathrm{M}$ formic acid ( $\mathrm{pH}$ 2.0) as running buffer. The LOD obtained using MS detection (1 ng/g) was 20 times lower than that obtained previously with UV detection. Figure 5B shows the extracted ion electropherogram obtained for glycine betaine, trigonelline and total carnitines in soybean oil sample, extra virgin olive oil sample, and oil mixture of extra virgin olive oil sample with a $5 \% \mathrm{w} / \mathrm{w}$ of soybean oil sample, as well as their $\mathrm{MS}^{2}$ spectra in the oil mixture. The improved sensitivity enabled to detect low quantities of trigonelline in olive oils, so that at this low level it cannot be used as adulteration marker. By contrast, carnitines were not detected or not quantifiable in extra virgin olive oils; however, they were present in seed oils. This fact made possible to propose them as a feasible novel marker for the detection of adulteration of olive oils with seed oils [8]. From the results obtained using the developed methodology for the determination of non-protein amino acids [7] and betaines [8], both included among the variety of compounds constituting the unsaponifiable fraction of oils, the potential of ornithine, alloisoleucine and carnitines as novel markers for the detection of olive oil adulteration was demonstrated . 


\section{Figure 5.}
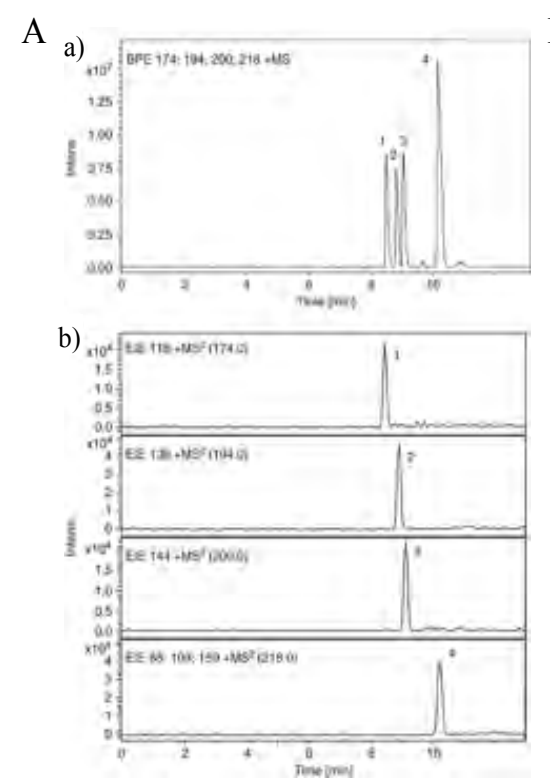

$\mathrm{B}$
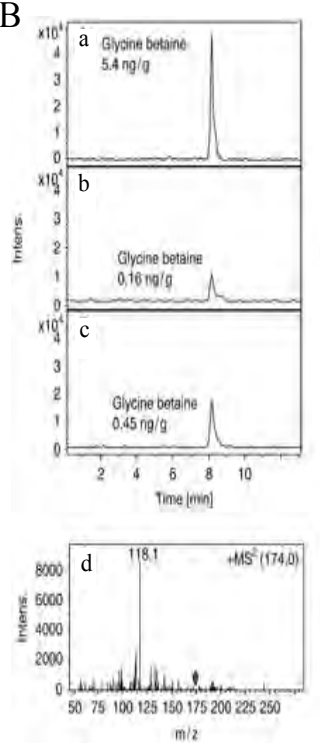
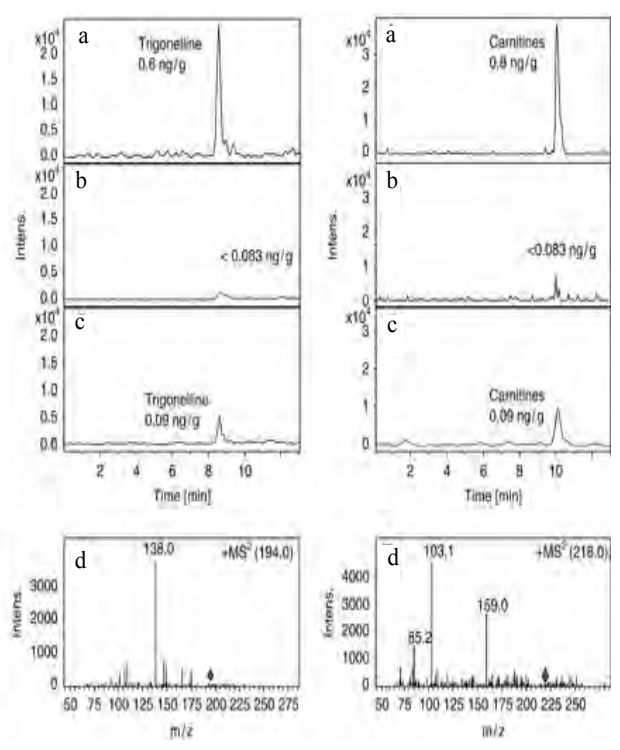

Fig. 5. A) CZE-MS base-peak electropherogram (a) and simultaneous CZE-MS ${ }^{2}$ extracted-ion electropherogram (EIE) (b) for standard betaines mixture $(5 \mu \mathrm{g} / \mathrm{mL}$ each one injected at 50 mbar x $15 \mathrm{~s}$ (a) or $50 \mathrm{~s}(\mathrm{~b})$ ). B) CZE-MS ${ }^{2}$ EIE for glycine betaine, trigonelline and total content of carnitines in (a) soybean oil sample, (b) extra virgin olive oil sample, (c) oil mixture of extra virgin olive oil sample with a $5 \% \mathrm{w} / \mathrm{w}$ of soybean oil sample, and (d) $\mathrm{MS}^{2}$ spectra for the peaks obtained in (c) of glycine betaine, trigonelline or carnitines in the oil mixtures of extra virgin olive oil sample with a $5 \% \mathrm{w} / \mathrm{w}$ of soybean oil sample. CZE conditions: BGE, 0.1M formic buffer ( $\mathrm{pH} 2.0$ ); uncoated fused-silica capillary, $50 \mu \mathrm{m}$ id x $60 \mathrm{~cm}$; voltage, $25 \mathrm{kV}$; temperature, $25^{\circ} \mathrm{C}$. ESI conditions: positive ion mode $(4.5 \mathrm{kV})$; sheath liquid, isopropanol/water $(50 / 50, \mathrm{v} / \mathrm{v})$ with $0.1 \%$ formic acid at $3.3 \mu \mathrm{L} / \mathrm{min}$; drying gas flow, $3 \mathrm{~L} / \mathrm{min}$; drying temperature, $300{ }^{\circ} \mathrm{C}$; nebulizer pressure, 2 psi. Ion trap conditions: maximum accumulation time, $300 \mathrm{~ms}$; averages, 1; scan, 50$280 \mathrm{~m} / \mathrm{z} . \mathrm{MS}^{2}$ transitions in MRM mode with width, $4 \mathrm{~m} / \mathrm{z}$; fragmentation amplitude 1.00 $\mathrm{V}$ and fragmentation time, $40 \mathrm{~ms}$. Reprinted from [8], copyright (2011) with permission from John Wiley and Sons. 
Carnitine (Carn) is produced from lysine and methionine in low levels in human, so it is mostly introduced by diet. Due to the important role that carnitine plays in the fatty acids metabolism, its deficiency could give rise to different health problems such as hypoglycemia, hyperammonemia and hypoketosis $[62,63]$. A CZE method with $\mathrm{C}^{4} \mathrm{D}$ detection was developed for the quantitative determination of carnitine in a great variety of foodstuffs (fruit, juices, milk, yogurt, cheese, chicken meat and red meat) [44]. This method consisted in the use of a $500 \mathrm{mM}$ acetic acid buffer containing $0.05 \%$ tween-20 (to prevent the wall interaction of the larger species) and a simple sample treatment. A LOD of $2.6 \mu \mathrm{M}$ was obtained. The main advantage of the developed CZE-C ${ }^{4} \mathrm{D}$ methodology is, undoubtedly, the elimination of the derivatization step or indirect approaches to carry out the determination of carnitine.

\subsection{Other amino acids.}

N-Phenylpropenoyl-L-amino acids (NPAs) are a group of non protein amino acids which are among the main contributors for the astringent taste of cocoa. For this reason, these compounds could be considered as useful quality markers concerning the cocoa's taste [64]. In addition, NPAs have also demonstrated to have different pharmacological activities. ${ }^{65}$ Lechtenberg et al. [45] proposed two alternative methodologies (CZE and UPLC, both with UV detection) to determine the NPA content in cocoa and cocoa products. As it can be observed in Table 1, two different CE systems were used, but in both the experimental conditions to achieve the NPAs separation were similar $(50 \mathrm{mM}$ sodium borate at $\mathrm{pH} 8.8$ was employed as running buffer). The CZE and UPLC methodologies developed in this work were comparable concerning the results obtained and time consumption. The former lacks in sensitivity but it just needed a simple sample treatment whereas the latter requires a SPE step in the sample cleanup but enables shorter 
analysis times and lower detection limits. Taking that into account, CZE was proposed for analyzing cocoa samples with high content of NPAs (mainly for the determination of N-[3'，4' -dihydroxy-(E)-cinnamoyl]-3-hydroxy-L-tyrosine (Caff-DOPA)，N-[3'，4'dihydroxy-(E)-cinnamoyl]-L-aspartic acid (Caff-Asp), and N-[4'-hydroxy-(E)cynnamoyl]-L-aspartic acid (pC-Asp) in cocoa beans and shells).

\section{Enantiomeric determination of non-protein amino acids in food by CE.}

As it has been described in the introduction of this review, enantioselective separations may provide relevant information in different food areas, such as food authenticity, detection of adulterations or evaluation of manufacturing processes among others. From the publication of the previous review devoted to describe the developed CE methods for the determination of non-protein amino acids in foods [1], the field of chiral separations has undergone a great growth. However, most of the chiral methodologies were aimed to the chiral separation of protein amino acids so it can be said that the chiral separation of non-protein amino acids in food samples is still a quite unexplored field.

Table 2 groups the main characteristics of the chiral methodologies developed to enantiomerically separate chiral non-protein amino acids by CE.

The most used CE mode has been MEKC which is based on the addition of a micellar pseudophase in which the concentration of the micellar system must be higher than its critical micelle concentration. The chiral selectors used in these methodologies were different types of cyclodextrins. CEC was also employed and compared with nano-

LC. As shown in Table 2, the two main detection systems used were UV and $\mathrm{MS}^{2}$ and in almost all the works a previous derivatization procedure was needed (labeling reagents employed were FMOC, FITC or AQC). 
Since the L-enantiomer is usually responsible for the beneficial biological properties, the aim of these works was usually its separation from the D-enantiomer that can have in some cases toxic properties and whose addition during the elaboration of foods is forbidden. The developed methodologies enabled in these cases to guarantee a good quality control of food products. Samples analyzed were mainly food supplements, infant formulas, fermented foods (such as wine, beer etc.), etc., as described in detail in

\section{Table 2.}


Table 2. Characteristics of the analytical methodologies developed for the enantiomeric determination of non protein amino acids by CE.

\begin{tabular}{|c|c|c|c|c|c|c|c|}
\hline Classification & Name (Abbr.) & $\begin{array}{l}\text { CE mode/detection } \\
\text { Separation conditions }\end{array}$ & $\begin{array}{l}\text { Separation } \\
\text { from: }\end{array}$ & Sample treatment & Application & LOD* & Ref. \\
\hline \multirow[t]{5}{*}{$\begin{array}{l}\text { Aliphatic amino } \\
\text { acids with } \\
\text { nitrogen in the } \\
\text { side chain }\end{array}$} & \multirow[t]{4}{*}{ Ornithine (Orn) } & $\begin{array}{l}\text { EKC-UV }(260 \mathrm{~nm}) \\
5 \%(\mathrm{~m} / \mathrm{v}) \mathrm{HS}-\beta-\mathrm{CD}+2 \%(\mathrm{~m} / \mathrm{v}) \\
\text { Ac- } \gamma-\mathrm{CD} \text { in } 50 \mathrm{mM} \text { phosphate } \\
(\mathrm{pH} 2.0) ; \text { capillary, } 50 \mu \mathrm{m} \times 40 \\
\text { or } 64 \mathrm{~cm} ;-25 \mathrm{kV}, 15^{\circ} \mathrm{C}\end{array}$ & $\begin{array}{l}20 \text { protein } \\
\text { amino acids, } \\
+ \text { GABA }\end{array}$ & $\begin{array}{l}\text { Filtration (beer was previously } \\
\text { degassed in a ultrasonic bath) } \\
\text { followed by AQC derivatization }\end{array}$ & $\begin{array}{l}\text { Analysis of Orn enantiomers in } \\
\text { fermented foods (beer, wine, } \\
\text { vinegar) }\end{array}$ & $9 \times 10^{-6} \mathrm{M}$ & [66] \\
\hline & & $\begin{array}{l}\text { EKC-UV }(260 \mathrm{~nm}) \\
5 \%(\mathrm{~m} / \mathrm{v}) \text { HS- } \beta-\mathrm{CD}+2 \%(\mathrm{~m} / \mathrm{v}) \\
\text { Ac- } \gamma-\mathrm{CD} \text { in } 50 \mathrm{mM} \text { phosphate } \\
(\mathrm{pH} 2.0) ; \text { capillary, } 50 \mu \mathrm{m} \times 64 \\
\mathrm{~cm} ;-25 \mathrm{kV}, 15^{\circ} \mathrm{C} ;\end{array}$ & Arg, Lys & $\begin{array}{l}\text { Dietary supplements: water solution, } \\
\text { filtration, and in-capillary } \\
\text { derivatization with AQC } \\
\text { Wine: Filtration and in-capillary } \\
\text { derivatization with AQC }\end{array}$ & $\begin{array}{l}\text { Determination of Orn, Arg and } \\
\text { Lys enantiomers in dietary } \\
\text { supplements and wines }\end{array}$ & $6.4 \times 10^{-6} \mathrm{M}$ & [67] \\
\hline & & $\begin{array}{l}\text { EKC- UV }(240 \mathrm{~nm}) \\
1 \mathrm{mM} \gamma-\mathrm{CD} \text { in } 100 \mathrm{mM} \text { borate } \\
(\mathrm{pH} 10.0) \text {; capillary, } 50 \mu \mathrm{m} x \\
40 \mathrm{~cm} ; 20 \mathrm{kV}, 25^{\circ} \mathrm{C} \text {; }\end{array}$ & Lys, Arg, Asp & $\begin{array}{l}\text { Water solution, filtration, dissolution } \\
\text { in borate buffer and accelerated } \\
\text { derivatization with FITC using a } \\
\text { ultrasound probe }\end{array}$ & $\begin{array}{l}\text { Enantiomeric determination of } \\
\text { Orn in food supplements }\end{array}$ & $1.6 \times 10^{-7} \mathrm{M}$ & [68] \\
\hline & & $\begin{array}{l}\text { EKC- }^{-M^{2}} \\
0.75 \mathrm{mM} \gamma \text {-CD in } 50 \mathrm{mM} \\
\text { ammonium carbonate }(\mathrm{pH} 10) \text {; } \\
\text { Capillary, } 50 \mu \mathrm{m} \times 100 \mathrm{~cm} ; 25 \\
\mathrm{kV}, 25^{\circ} \mathrm{C}\end{array}$ & - & $\begin{array}{l}\text { Degasification (ultrasonic bath), } \\
\text { filtration, } \mathrm{pH} \text { adjustment ( } \mathrm{pH} \text { 10), } \\
\text { and filtration prior to FITC } \\
\text { derivatization }\end{array}$ & $\begin{array}{l}\text { Enantiomeric determination of } \\
\text { beers submitted to different } \\
\text { fermentation processes }\end{array}$ & $2.5 \times 10^{-9} \mathrm{M}$ & [12] \\
\hline & Citrulline (Cit.) & $\begin{array}{l}\text { CEC-UV }(210,260 \mathrm{~nm}) \\
0.5 \mathrm{M} \text { ammonium } \\
\text { formate } / \mathrm{H}_{2} \mathrm{O} / \mathrm{ACN}(1 / 19 / 80, \\
\mathrm{v} / \mathrm{v} / \mathrm{v})(\mathrm{pH} 2.5) ; \text { capillary, } 100 \\
\mu \mathrm{m} \times 32.5 \mathrm{~cm} ;-10 \mathrm{kV}, 35^{\circ} \mathrm{C}\end{array}$ & - & $\begin{array}{l}\text { Water solution and FMOC } \\
\text { derivatization before CE analysis }\end{array}$ & $\begin{array}{l}\text { Determination of L-citrulline } \\
\text { and its enantiomeric impurity } \\
\text { in food supplements }\end{array}$ & $7.5 \times 10^{-7} \mathrm{M}$ & [17] \\
\hline
\end{tabular}




\section{Table 2. Continued}

\begin{tabular}{|c|c|c|c|c|c|c|c|}
\hline Classification & Name (Abbr.) & $\begin{array}{l}\text { CE mode/detection } \\
\text { Separation conditions }\end{array}$ & $\begin{array}{l}\text { Separation } \\
\text { from: }\end{array}$ & Sample treatment & Application & LOD* & Ref. \\
\hline Betaines & Carnitine (Carn) & $\begin{array}{l}\text { EKC- } \mathrm{MS}^{2} \\
10 \mathrm{mM} \text { Succ- } \gamma-\mathrm{CD} \text { in } 0.5 \\
\text { M ammonium formate }(\mathrm{pH} \\
2.5) \text { using PFT; capillary, } \\
50 \mu \mathrm{m} \text { x } 75 \mathrm{~cm} ; 25 \mathrm{kV} ; 25 \\
{ }^{\circ} \mathrm{C}\end{array}$ & - & $\begin{array}{l}\text { Water solution (sonication) followed by } \\
\text { ultrafiltration ( } 5 \mathrm{kDa} \text { cut-off filter) and } \\
\text { water dissolution before FMOC } \\
\text { derivatization }\end{array}$ & $\begin{array}{l}\text { Quantitative analysis of D/L- } \\
\text { carnitine in infant formulas. } \\
\text { Detection of D-carnitine up to } 8 \\
\% \text {. }\end{array}$ & $16 \mathrm{ng} / \mathrm{mL}$ & [69] \\
\hline & & $\begin{array}{l}\text { EKC- } \mathrm{MS}^{2} \\
0.2 \%(\mathrm{~m} / \mathrm{v}) \text { Succ- } \gamma \text {-CD in } \\
0.5 \mathrm{M} \text { ammonium formate } \\
(\mathrm{pH} 2.5) ; \text { capillary, } 50 \mu \mathrm{m} \\
\mathrm{x} 100 \mathrm{~cm} ; 25 \mathrm{kV} ; 25^{\circ} \mathrm{C}\end{array}$ & - & $\begin{array}{l}\text { Drinks: Water solution + FMOC } \\
\text { derivatization } \\
\text { Biscuits, tablets, and capsules: Water } \\
\text { extraction, centrifugation, dilution } 1 / 10 \\
\text { in water + FMOC derivatization }\end{array}$ & $\begin{array}{l}\text { Identification and quantification } \\
\text { of D/L-carnitine in dietary food } \\
\text { supplements (drinks, biscuits, } \\
\text { capsules and tablets). The use of } \\
\text { racemic carnitine (not allowed by } \\
\text { the legistation) was corroborated. } \\
\text { in one of the food sample } \\
\text { analyzed }\end{array}$ & $10 \mathrm{ng} / \mathrm{mL}$ & [18] \\
\hline $\begin{array}{l}\text { Other amino } \\
\text { acid }\end{array}$ & $\begin{array}{l}\text { S-adenosyl-L-methionine } \\
\text { (SAM) }\end{array}$ & $\begin{array}{l}\text { CE-UV }(260 \mathrm{~nm}) \\
300 \mathrm{mM} \text { glycine- } 50 \mathrm{mM} \\
\text { phosphate }(\mathrm{pH} 2.5) ; \\
\text { capillary, } 50 \mu \mathrm{m} \text { x } 50 \mathrm{~cm} \text {; } \\
25 \mathrm{kV}, 25^{\circ} \mathrm{C}\end{array}$ & - & $\begin{array}{l}\text { Freezing, Liquid-liquid extraction ( } 5 \% \\
\text { TCA (w/v)), centrifugation and } \\
\text { filtration prior to CE analysis. }\end{array}$ & $\begin{array}{l}\text { Quantification of SAM in fruits } \\
\text { and fruit juices }\end{array}$ & $0.5 \mu \mathrm{M}^{\mathrm{a}}$ & {$[70]$} \\
\hline
\end{tabular}

* LODs units expressed as in the original work. These LODs are referred to the injected solutions of standard samples except for a) in which LODs is referred to the injected solutions of food samples. ${ }^{*}$ Capillary dimension expressed as internal diameter $\mathrm{x}$ effective length ( $\mathrm{cm}$ to the detector).

ACN, acetonitrile; Ac- $\gamma$-CD, acetylated- $\gamma$-CD; AQC, 6 -aminoquinolyl- $N$-hydroxysuccinimidyl carbamate; Arg, arginine; Asp, asparagine; GABA, $\gamma$-aminobutiric acid; $\gamma$-CD, $\gamma$-cyclodextrin; FITC, fluorescein isothiocyanate; FMOC, 9-Fluorenylmethoxycarbonylchloride; HS- $\beta$-CD, highly sulfated- $\beta$-cyclodextrin; Lys, lysine; MS 2 , tandem mass spectrometry; PFT, partial filling technique; Succ- $\gamma$-CD, succinyl- $\gamma$-cyclodextrin; TCA, trichloroacetic acid 


\subsection{Aliphatic amino acids with nitrogen in the side chain}

Ornithine (Orn) and Citrulline (Cit) enantiomers were determined in foods by CE under the experimental conditions detailed in Table 2.

Ornithine is a non-protein amino acid whose enantiomeric separation is receiving huge attention due to the beneficial properties of the L-enantiomers and the harmful effects of D-orn. L-Orn plays an important role in some biochemical processes such as fatty acid excess metabolism, human growth hormone synthesis, ammonia detoxification in urea cycle, synthesis of L-proline, etc. In contrast, D-enantiomer, which may occur during food processing or fermentation processes [71], can produce depletion in the urea synthesis giving toxic consequences. Humans can obtain L-orn through endogenous synthesis involving urea cycle, as well as from fermented foods (such as beer, wine, juices, cheese, etc), or functional foods (such as dietary supplements) [72]. To analyze Orn enantiomers in fermented foods, an EKC-UV method was developed by Martínez Girón et al. enabling LODs of $9 \times 10^{-6} \mathrm{M}$. The method consisted of using AQC as off-line derivatizing reagent and $50 \mathrm{mM}$ phosphate $(\mathrm{pH} 2.0)$ containing $5 \%(\mathrm{~m} / \mathrm{v})$ HS- $\beta-\mathrm{CD}$ and $2 \%(\mathrm{~m} / \mathrm{v})$ acetylated- $\gamma-\mathrm{CD}$ as BGE [66]. As shown in Figure 6, the methodology allowed the enantiomeric separation of ornithine (in less than $15 \mathrm{~min}$ ) as well as the separation of the enantiomers of this amino acid from the enantiomers of the chiral amino acids contained in a mixture of the twenty protein amino acids and GABA in about $45 \mathrm{~min}$. To short the analysis time and to increase CE method automatization, the same authors developed a second method using in-capillary derivatization [67] with the aim of determining Orn, arginine and lysine enantiomers in wine samples (this compounds have demonstrated to be responsible of wine's organoleptic properties) and dietary supplements. The enantiomeric separation of Orn could also be performed with FITC as labeling reagent. To do that, Domínguez-Vega et al. [68] employed an ultrasound probe 
which allowed to reduce derivatization time from $16 \mathrm{~h}$ to $10 \mathrm{~min}$. The developed EKCUV method enabled the enantiomeric analysis of this amino acid with LODs of $1.6 \times 10^{-}$ ${ }^{7} \mathrm{M}$, as well as the separation from the enantiomers of other protein amino acids such as lysine, arginine and asparagine (see other CE conditions in Table 2) in food supplements. Moreover, to enhance the sensitivity and selectivity in the enantiomeric determination of ornithine in beers, an interesting EKC-MS ${ }^{2}$ method using the previous derivatization procedure was proposed. The method, based on the use of a $50 \mathrm{mM}$ ammonium carbonate buffer at $\mathrm{pH} 10.0$ containing $0.75 \mathrm{mM} \gamma-\mathrm{CD}$ as BGE, enabled to quantify the content of the Orn enantiomers in beers submitted to different fermentation processes with LODs of $2.5 \times 10^{-9} \mathrm{M}$. The percentages for D-Orn in the analyzed samples ranged from $1.5 \%$ to $10 \%$, the lowest value corresponding to a dietetic beer and the maximum to a double fermentation beer [12]. The four EKC methodologies described in the literature to carry out the chiral separation of ornithine show that this non-protein amino acid can be separated both under acid and basic conditions using different cyclodextrins as chiral selectors, depending on the characteristics of the analyzed samples or the requirements needed to perform the derivatization step. In any case, the lowest LODs for ornithine are achieved using a CE-MS² methodology. 


\section{Figure 6.}
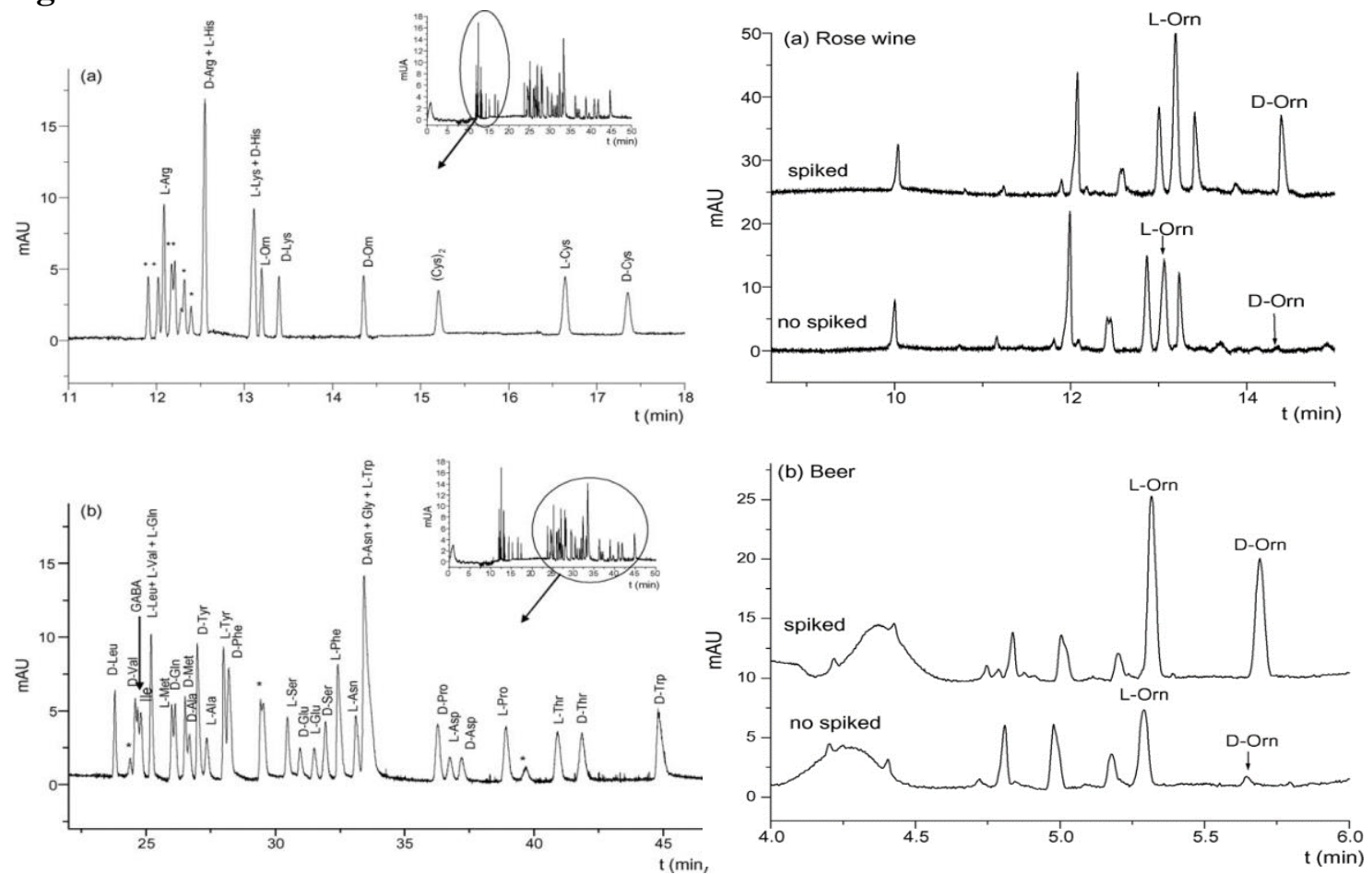

Fig. 6. A) Enantiomeric separation by EKC of a mixture of the 20 protein amino acids,

Orn, and GABA (upper corner) divided in two migration zones: (a) first-migrating zone, and (b) second-migrating zone. B) Electropherograms corresponding to different fermented foods derivatized off-line with AQC (a) a rose wine (uncoated fused-silica, 50 $\mu \mathrm{m} \times 72.5 \mathrm{~cm}$; injection by pressure, $5066.25 \mathrm{~Pa}$ for $20 \mathrm{~s}$ of sample followed of $5 \mathrm{~s}$ of BGE; non-spiked sample and sample spiked with $2.5 \times 10^{-5} \mathrm{M}$ racemic Orn) and (b) a beer (uncoated fused-silica, $50 \mu \mathrm{m} \times 48.5 \mathrm{~cm}$; injection by pressure, $5066.25 \mathrm{~Pa}$ for $5 \mathrm{~s}$ of sample followed of $5 \mathrm{~s}$ of BGE; non spiked sample and sample spiked with $5 \times 10^{-4} \mathrm{M}$ racemic Orn). EKC conditions: $50 \mathrm{mM}$ phosphate buffer ( $\mathrm{pH} 2.0)$ containing $5 \%(\mathrm{~m} / \mathrm{v})$ HS- $\gamma-\mathrm{CD}$ and $2 \%(\mathrm{~m} / \mathrm{v})$ acetylated- $\gamma-\mathrm{CD}$; uncoated fused-silica, $50 \mu \mathrm{m} \times 72.5 \mathrm{~cm}$; voltage, $-25 \mathrm{KV}$; temperature, $15^{\circ} \mathrm{C}$. (*) Unknown peaks. Reprinted from [66], copyright (2008) with permission from Elsevier.

Citrulline is a non-protein amino acid which has also demonstrated to have different enantiomeric behavior. L-Cit, which is naturally occurring, is precursor of 
protein amino acid Arginine, it is involved in urea cycle and it plays an important role in ammonia level decrease and NO cycle [73]. To carry out the enantiomeric determination of citrulline in food suplements, a CEC-UV method was developed using cellulose tris (3-chloro-4-methylphenylcarbamate chiral stationary phase (CSPs) as chiral selector, 9fluorenylmethoxycarbonylchloride (FMOC) as labeling reagent and $0.5 \mathrm{M}$ ammonium formate as running buffer. The method, which demonstrated to be more efficient in comparison with the developed nano-LC method, gave rise to LODs of $7.5 \times 10^{-7} \mathrm{M}$ for citrulline and made possible to achieve the enantiomeric determination of nineteen more amino acids (among twenty three amino acids analyzed) [17].

\subsection{Betaines}

As above-mentioned, Carn is synthesized from lysine and methionine or it can be available to human through some dietary sources. It has shown to have different biological activities depending on its enantiomeric form. L-Carn has demonstrated to play an important role in long chain fatty acids metabolism while D-Carn posseses toxical properties $[62,74]$. For these reasons, the development of a method allowing to monitor the content of L/D-Carn in food samples is of great interest in order to carry out a correct quality control. With this aim, a CE-ESI-MS² methodology was developed using FMOC as labeling reagent (derivatization at $45^{\circ} \mathrm{C}$ for $60 \mathrm{~min}$ ) and $0.5 \mathrm{M}$ ammonium formate containing $10 \mathrm{mM}$ Succ- $\gamma-\mathrm{CD}$ as running buffer. Firstly, a partial filling technique (PFT) was employed and the method gave rise to LODs of $0.1 \mu \mathrm{M}$ of L-Carn. The analysis of carnitine enantiomers in 14 infant formulas supplemented with this amino acid enabled the detection of amounts as high as $8 \%$ of the toxic enantiomer which exceeded by far the limits established by the European Pharmacopeia [69]. Afterwards, in order to avoid the use of the PFT technique, the method was optimized without this step by using $0.2 \%$ 
$(\mathrm{m} / \mathrm{v})$ Succ- $\gamma-\mathrm{CD}$ as chiral selector with a longer length capillary (see table 2) [18] improving the precision and sensitivity of the previous method (LODs of $10 \mathrm{ng} / \mathrm{mL}$ for D/L-Carn enantiomers were obtained enabling to detect enantomeric impurities up to $0.025 \%)$. In this case, the optimized method was applied to the analysis of 22 dietary food supplements showing the use of L-Carn in 21 samples with enantiomeric impurities (D-Carn) up to $6 \%$. The use of racemic Carn (not allowed by the legislation) in one of the food supplements was corroborated which confirmed the need of analytical methodologies to ensure food quality [18].

\subsection{Other amino acids}

The only non-protein amino acid included in this group is S-Adenosyl-Lmethionine (SAM), which is a chiral compound involved in many biochemical pathways and the major methyl donor in living organisms [75]. It is synthesized from methionine in the presence of ATP [76]. In addition, two diastereoisomers of this compound exist, known as (S,S)- and (R,S)-S-adenosyl-L-methionine, among which only one has demonstrated to be biologically active (S,S-). Van de Poel et al. [70] demonstrated that SAM content varies depending on food processing (relationship between heat treatment and SAM content in tomato samples is shown in Figure 7A, 7B). The developed method consisted of optimizing CE-UV conditions to quantify SAM contents in different fruit tissue samples. The use of $300 \mathrm{mM}$ glycine-50 mM phosphate ( $\mathrm{pH} 2.5)$ was chosen as optimum running buffer, and the method, compared with the use of HPLC, made possible to enhance the enantiomeric separation (see Figure 7A) with minimum sample treatment, in half time and with LODs 2-fold lower than those obtained by the conventional methodology (see LOD and other CE conditions in Table 2). 


\section{Figure 7.}

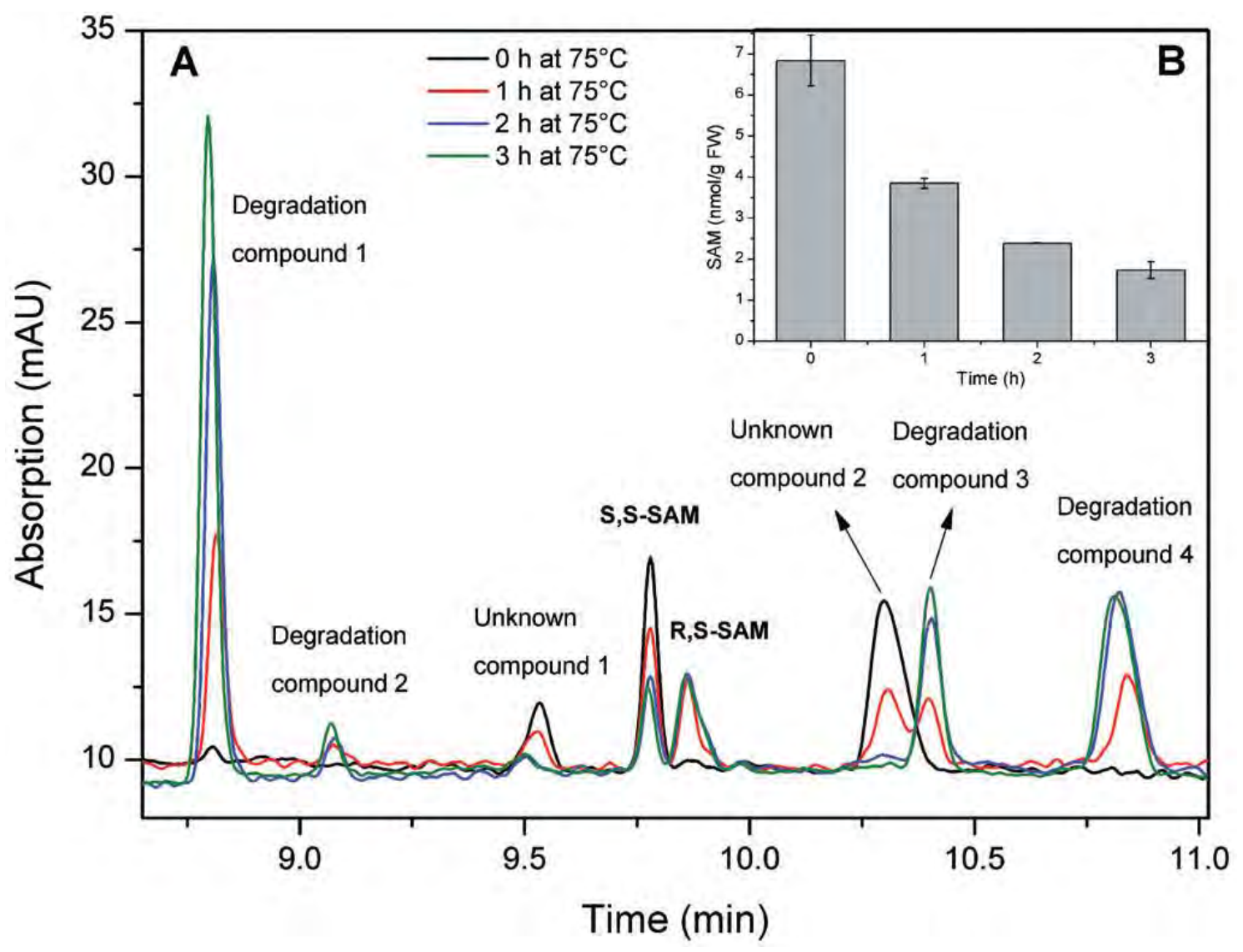

Fig. 7. (A) Partial CE electropherogram showing the heat degradation of a tomato extract during several hours at $75{ }^{\circ} \mathrm{C} . S, S$-SAM degrades together with two other unknown compounds (unknown compounds 1 and 2). Four degradation compounds (degradation compounds 1-4) are formed due to the heat treatment. (B) Inset showing SAM concentration $(\mathrm{nmol} / \mathrm{g} \mathrm{FW})$ in tomato extracts during heat treatment of several hours at $75^{\circ} \mathrm{C}$. Error bars indicate the standard deviation based on two repetitions. Reprinted from [70], copyright (2010) with permission from John Wiley and Sons.

\section{Concluding remarks}

Non protein amino acids have shown to have a high potential as quality markers of foods. Their presence can be related to the food processing or to the existence of 
fraudulent practices so the development of analytical methodologies for their determination is very relevant. From the high number of research works described in the literature during the period of time covered by this review, it is quite clear that $\mathrm{CE}$ and MCE possess attractive capabilities to carry out the sensitive determination of non protein amino acids in a big variety of food matrices such as beverages (tea, milk, energy drinks, etc.), flour products, oil, vegetables (tomato, cucumber, spinach, etc.), food supplements, infant formulas, among others. The developed methodologies have demonstrated to be competitive in terms of sensitivity and selectivity with those involving other more conventional techniques and to present some advantages such as the low consumption of sample and solvents, the high speed of analysis and high separation efficiencies. Hence, $\mathrm{CE}$ techniques are nowadays not only promising techniques but real alternatives in food analysis. In most cases, a derivatization step is required in order to introduce chromophore or fluorophore groups into the molecule of non-protein amino acids or to enhance the sensitivity obtained by different detection systems including MS. With this aim, a variety of labeling reagents has been employed such as FTIC, FMOC, NBD-Cl, DMDSPAB-1 or AQC. The latest trend in this topic involves the development of in-capillary derivatization procedures in which the labeling agent is inserted into the capillary for direct derivatization before CE separation. In this way, laborious and time consuming offline derivatization protocols could be avoided.

The chiral separation of non-protein amino acids in food samples has received much attention in the last years. The use of a chiral selector in the separation buffer (EKC or MEKC modes) or a chiral stationary phase (CEC mode) has enabled the separation of the enantiomers of chiral non protein amino acids giving the proposed methodologies additional information of relevance in the control of the quality and safety of foods taking into account that the addition of the D-enantiomer during food production is forbidden 
and that racemization can occur as a consequence of some food processing or microbiological contamination.

Regarding detection systems, UV, fluorescence and MS have been the most employed detectors enabling reaching LODs at the level of $10^{-9} \mathrm{M}$. Despite the relatively poor concentration sensitivity related to the use of UV detection, this detector is the most employed in CE analysis of non-protein amino acids in foods. This fact is due to economic and availability reasons but also the development of in capillary sample preconcentration techniques based on electrophoretic principles which enable to overcome the sensitivity limitations in CE with optical detection.

Due to the high number of non-protein amino acids that exist in food samples, it can be said that their full potential as quality markers in foods remain unexplored. For this reason it can be expected than new methodologies with advances at different level (sample treatment, derivatization, preconcentration, CE separation, etc) will continue to grow in the near future.

\section{Acknowledgements}

Authors thank the Comunidad of Madrid (Spain) and European funding from FEDER program for research project (S2013/ABI-3028, AVANSECAL-CM). M.C.P. also thanks the Ministry of Economy and Competitiveness (Spain) for her "Ramón y Cajal" research contract (RYC-2013-12688). R.P.M. thanks the University of Alcalá for her pre-doctoral contract. 


\section{References}

[1] M. Castro-Puyana, A. L. Crego, M. L. Marina, C. García-Ruiz, CE methods for the determination of non-protein amino acids in foods, Electrophoresis 28 (2007) 4031-4045.

[2] M. Herrero, C. Simó, V. García-Cañas, S. Fanali, A. Cifuentes, Chiral capillary electrophoresis in food analysis, Electrophoresis 31 (2010) 2106-2114.

[3] A. Rocco, Z. Aturki, S. Fanali, Chiral separations in food analysis, TrAC, Trends Anal. Chem. 52 (2013) 206-225.

[4] F. Kvasnička., Capillary electrophoresis in food authenticity, J. Sep. Sci. 28 (2005) $813-825$.

[5] R. W. Peace, G. S. Gilani, Chromatographic determination of amino acids in foods, J. AOAC Int. 88 (2005) 877-887.

[6] S. Hunt, The non-protein amino acids, in Barret, G. C., ed., Chemistry and Biotechnology of amino acids, Oxford Polytechnic, 1985, pp. 55.

[7] L. Sanchez-Hernández, M. L. Marina, A. L. Crego, A capillary electrophoresistandem mass spectrometry methodology for the determination of non-protein amino acids in vegetable oils as novel markers for the detection of adulterations in olive oils, J. Chromatogr. A 1218 (2011) 4944-4951.

[8] L. Sanchez-Hernández, M. Castro-Puyana, M. L. Marina, A. L. Crego, Determination of betaines in vegetable oils by capillary electrophoresis tandem mass spectrometryapplication to the detection of olive oil adulteration with seed oils, Electrophoresis 32 (2011) 1394-1401.

[9] C. Bignardi, A. Cavazza, M. Rinaldi, C. Corradini, R. Massini, Evaluation of thermal treatment markers in wheat flour-derived products cooked in conventional and in lowemissivity ovens, Food Chem. 140 (2013) 748-754. 
[10] R. Mandrioli, L. Mercolini, M. A. Raggi, Recent trends in the analysis of amino acids in fruits and derived foodstuffs, Anal. Bioanal. Chem. 405 (2013) 7941-7956.

[11] W. Wu, X. Wu, X. Lin, Z. Xie, J. P. Giesy, Quantification of domoic acid in shellfish tissues by pressurized capillary electrochromatography, J. Sep. Sci. 32 (2009) 2117-2122. [12] E. Domínguez-Vega, L. Sánchez-Hernández, C. García-Ruiz, A. L. Crego, M. L. Marina, Development of a CE-ESI-ITMS method for the enantiomeric determination of the non-protein amino acid ornithine, Electrophoresis 30 (2009) 1724-1733.

[13] M. Friedman, C. E. Levin, Nutritional and medicinal aspects of D-amino acids, Amino acids 42 (2012) 1553-1582.

[14] M. Friedman, Origin, microbiology, nutrition, and pharmacology of D-amino acids, Chem. Biodiversity 7 (2010) 1491-1529.

[15] D. W. Armstrong, C. D. Chang, W.Y. Li, Relevance of enantiomeric separations in food and beverage analyses, J. Agric. Food Chem. 38 (1990) 1674-1677.

[16] A. Giuffrida, G. Maccarrone, V. Cucinotta, S. Orlandini, A. Contino, Recent advances in chiral separation of amino acids using capillary electromigration techniques, J. Chromatogr. A 1363 (2014) 41-50.

[17] E. Domínguez-Vega, A. L. Crego, K. Lomsadze, B. Chankvetadze, M. L. Marina, Enantiomeric separation of FMOC-amino acids by nano-LC and CEC using a new chiral stationary phase, cellulose tris(3-chloro-4-methylphenylcarbamate), Electrophoresis 32 (2011) 2700-2707.

[18] L. Sánchez-Hernández, M. Castro-Puyana, C. García-Ruiz, A. L. Crego, M. L. Marina, Determination of L- and D-carnitine in dietary food supplements using capillary electrophoresis-tandem mass spectrometry, Food Chem. 120 (2010) 921-928.

[19] V. García-Cañas, A. Cifuentes, Recent advances in the application of capillary electromigration methods for food analysis, Electrophoresis 29 (2008) 294-309. 
[20] V. Poinsot, V. Ong-Meang, P. Gavard, F. Couderc, Recent advances in amino acid analysis by capillary electromigration methods, 2011-2013, Electrophoresis 35 (2014) $50-68$.

[21] A. Giuffrida, G. Maccarrone, V. Cucinotta, S. Orlandini, A. Contino, Recent advances in chiral separation of amino acids using capillary electromigration techniques J. Chromatogr. A 1363 (2014) 41-50.

[22] Y-P. Lin, Y-S. Su, J-F. Jen, Capillary electrophoretic analysis of $\gamma$-aminobutyric acid and alanine in tea with in-capillary derivatization and fluorescence detection, J. Agric. Food Chem. 55 (2007) 2103-2108.

[23] Y-S. Su, Y-P. Li, F-C. Cheng, J-F. Jen, In-capillary derivatization and stacking electrophoretic analysis of $\gamma$-aminobutyric acid and alanine in tea samples to redeem the detection after dilution to decrease matrix interference, J. Agric. Food Chem. 58 (2010) 120-126.

[24] S. Akamatsu, T. Mitsuhashi, Development of a simple analytical method using capillary electrophoresis-tandem mass spectrometry for product identification and simultaneous determination of free amino acids in dietary supplements containing royal jelly, J. Food Compos. Anal. 30 (2013) 47-51.

[25] H-Y. Hsiao, R. L. C. Chen, T-J. Cheng, Determination of tea fermentation degree by a rapid micellar electrokinetic chromatography, Food Chem. 120 (2010) 632-636.

[26] J. Yan, Y. Cai, Y. Wang, X. Lin, H. Li, Simultaneous determination of amino acids in tea leaves by micellar electrokinetic chromatography with laser-induced fluorescence detection, Food Chem. 143 (2014) 82-89.

[27] A. R. Piergiovanni, A. Damascelli, L-homoarginine accumulation in grass pea (Lathyrus sativus L.) dry seed. A preliminary survey, Food Nutr. Sci. 2 (2011) 207-213. 
[28] M. S. Baptista, R. C. C. Cianca, V. R. Lopes, C. M. R. Almeida, V. M. Vasconcelos, Determination of the non-protein amino acid $\beta$-N-methylamino-L-alanine in estuarine cyanobacteria by capillary electrophoresis, Toxicon 58 (2011) 410-414.

[29] M. Amigo-Benavent, M. Villamiel, M. D. del Castillo, Chromatographic and electrophoretic approaches for the analysis of protein quality of soy beverages, J. Sep. Sci. 30 (2007) 502-507.

[30] C. Bignardi, A. Cavazza, C. Corradini, Determination of furosine in food products by capillary zone electrophoresis-tandem mass spectrometry, Electrophoresis 33 (2012) 2382-2389.

[31] X-W. Zhang, Z-X. Zhang, Quantification of domoic acid in shellfish samples by capillary electrophoresis-based enzyme immunoassay with electrochemical detection, Toxicon 59 (2012) 626-632.

[32] A. Zinellu, S. Sotgia, S. Bastianina, R. Chessa, L. Gaspa, F. Franconi, L. Deiana, C. Carru, Taurine determination by capillary electrophoresis with laser-induced fluorescence detection: from clinical field to quality food applications, Amino Acids 36 (2009) 35-41.

[33] B. Vochyánová, F. Opekar, P. Tůma, Simultaneous and rapid determination of caffeine and taurine in energy drinks by MEKC in a short capillary with dual contactless conductivity/photometry detection, Electrophoresis 35 (2014) 1660-1665.

[34] S. Götz, T. Revermann, U. Karst, Quantitative on-chip determination of taurine in energy and sports drinks, Lab. Chip. 7 (2007) 93-97.

[35] M. Wu, F. Gao, Y. Zhang, Q. Wang, H. Li, Sensitive analysis of amino acids and vitamin B3 in functional drinks via field-amplified stacking with reversed-field stacking in microchip electrophoresis, Talanta 131 (2015) 624-631. 
[36] L-Y. Zhang, F-Q. Tu, X-F. Guo, H. Wang, P. Wang, H-S. Zhang, Rapid and sensitive determination of free thiols by capillary zone electrophoresis with near-infrared laser-induced fluorescence detection using a new BODIPY-based probe as labeling reagent, Electrophoresis 35 (2014) 2951-2958.

[37] H. Horie, K-I. Yamashita, Non-derivatized analysis of methiin and alliin in vegetables by capillary electrophoresis, J. Chromatogr. A 1132 (2006) 337-339.

[38] R. Kubec, E. Dadáková, Quantitative determination of S-alk(en)ylcysteine-S-oxides by micellar electrokinetic capillary chromatography, J. Chromatogr. A 1212 (2008) 154157.

[39] M. A. Mazorra-Manzano, M. J. Torres-Llanez, A. F. González-Córdova, B. VallejoCordoba, A capillary electrophoresis method for the determination of hydroxyproline as a collagen content index in meat products, Food. Anal. Methods 5 (2012) 464-470.

[40] Y-L. Dong, N. Yan, X. Li, X-M. Zhou, L. Zhou, H-J. Zhang, X-G. Chena, Rapid and sensitive determination of hydroxyproline in dairy products using micellar electrokinetic chromatography with laser-induced fluorescence detection, J. Chromatogr. A 1233 (2012) 156-160.

[41] Y. Zhao, J. Zheng, M. Yang, G. Yang, Y. Wu, F. Fu, Speciation analysis of selenium in rice samples by using capillary electrophoresis-inductively coupled plasma mass spectrometry, Talanta 84 (2011) 983-988.

[42] U. Kalsoom, M. C. Breadmore, R. M. Guijts, M. C. Boyce, Evaluation of potential cationic probes for the detection of proline and betaine, Electrophoresis 35 (2014) 33793386.

[43] L. Sánchez-Hernández, P. Puchalska, C. García-Ruiz, A. L. Crego, M. L. Marina, Determination of trigonelline in seeds and vegetable oils by capillary electrophoresis as 
a novel marker for the detection of adulterations in olive oils, J. Agric. Food Chem. 58 (2010) 7489-7496.

[44] W. Pormsila, S. Krähenbül, P. C. Hauser, Determination of carnitine in food and food supplements by capillary electrophoresis with contactless conductivity detection, Electrophoresis 31 (2010) 2186-2191.

[45] M. Lechtenberg, K. Henschel, U. Liefländer- Wulf, B. Quandt, A. Hensel, Fast determination of N-phenylpropenoyl-L-amino acids (NPA) in cocoa samples from different origins by ultra-performance liquid chromatography and capillary electrophoresis, Food Chem. 135 (2012) 1676-1684.

[46] F. E. Bloom, L. L. Iversen, Localizing 3H-GABA in nerve terminals of rat cerebral cortex by electron microscopic autoradiography, Nature 229 (1971) 628-630.

[47] L. Sivilotti, A. Nistri, GABA receptor mechanisms in the central nervous system, Prog. Neurobiol. 36 (1991) 35-92.

[48] Y. Abe, S. Umemura, K-I. Sugimoto, N. Hirawa, Y. Kato, N. Yokoyama, T. Yokoyama, J. Iwai, M. Ishii, Effect of green tea rich in $\gamma$-aminobutyric acid on blood pressure of Dahl salt-sensitive rats, Am. J. Hypertens. 8 (1995) 74-79.

[49] K. Kimura, M. Ozeki, L. R. Juneja, H. Ohira, L-theanine reduces psychological and physiological stress responses, Biol. Psychol. 74 (2007) 34-45.

[50] E. A. Bell, Non protein amino acids of plants: significance in medicine, nutrition, and agriculture, J. Agric. Food Chem. 51 (2003) 2854-2865.

[51] M. Z. Shamin, M. S. Hossain, K. Islam, H. K. M. Yusuf, F. Lambein. Mechanism of ODAP toxicity in one-day-old chicks, J. Biol. Sci. 11 (2002) 1-7.

[52] T. C. Breitner, Presence of homoarginine in gene activator-repressor histones may be the direct cause of most cancers, Speculations Sci. Technol. 11 (1988) 328-329. 
[53] V. L. Dawson, T. M. Dawson, E. D. London, D. S. Bredt, S. H Snyder, Nitric oxide mediates glutamate neurotoxicity in primary cortical cultures, Proc. Natl. Acad. Sci. 88 (1991) 6368-6371.

[54] V. T. Karamyan, R. C. Speth, Animal models of BMAA neurotoxicity: a critical review, Life Sciences 82 (2008) 233-246.

[55] M. Esterhuizen, T.G. Downing, beta-N-methylamino-L-alanine (BMAA) in novel South African cyanobacterial isolates, Ecotoxicol. Environ. Saf. 71 (2008) 309-313.

[56] Y. He, A. Fekete, G. Chen, M. Harir, L. Zhang, P. Tong, P. Schmitt-Kopplin, Analytical approaches for an important shellfish poisoning agent: Domoic acid, J. Agric. Food Chem. 58 (2010) 11525-11533.

[57] F. Geu-Flores, C. Böttcher, C. E. Olsen, D. Scheel, B. A. Halkier, Cytosolic $\gamma-$ glutamyl peptidases process glutathione conjugates in the biosynthesis of glucosinolates and camalexin in Arabidopsis, The Plant Cell 23 (2011) 2456-2469.

[58] M. Liu, X. Q. Li, C. Weber, C. Y. Lee, J. Brown, R. H. Liu, Antioxidant and antiproliferative activities of raspberries, J. Agric. Food Chem. 50 (2002) 2926-2930.

[59] R. Kubec, M. Hrbacova, R. A. Musah, J. Velisek, Allium discoloration: precursors involved in onion pinking and garlic greening, J. Agric. Food Chem. 52 (2004) 50895094.

[60] L. Servillo, A. Giovane, M. L. Balestrieri, A. Bata-Csere, D. Cautela, D. Castaldo, Betaines in fruits of citrus genus plants, J. Agric. Food Chem. 59 (2011) 9410-9416. [61] J. A. Duke, in Handbook of Medicinal Herbs, ed. CRC Press, New York, 2001, pp 297.

[62] J. Bremer, Carnitine-metabolism and functions, Physiol. Rev. 63 (1983) 14201480. 
[63] J. Demarquoy, W. Georges, C. Rigault, M. C. Royer, A. Clairet, M. Soty, S. Lekounoungou, F. Le Borgne, Radioisotopic determination of L-carnitine content in foods commonly eaten in western countries, Food Chem. 86 (2004) 137-142.

[64] T. Stark, T. Hofmann, Isolation, structure determination, synthesis, and sensory activity of N-Phenylpropenoyl-L-amino acids from Cocoa (Theobroma cacao), J. Agric. Food Chem. 53 (2005) 5419-5428.

[65] A. Hensel, A. M. Deters, G. Müller, T. Stark, N. Wittschier, T. Hofmann, Occurrence of N-phenylpropenoyl-L-amino acid amides in different herbal drugs and their influence on human keratinocytes, on human liver cells and on adhesion of Helicobacter pylori to the human stomach, Planta Medica 73 (2007) 142-150.

[66] A. B. Martínez-Girón, E. Domínguez-Vega, C. García-Ruiz, A. L. Crego, M. L. Marina, Enantiomeric separation of ornithine in complex mixtures of amino acids by EKC with off-line derivatization with 6-aminoquinolyl-N-hydroxysuccinimidyl carbamate, J. Chromatogr. B 875 (2008) 254-259.

[67] A. B. Martínez-Girón, C. García-Ruiz, A. L. Crego, M. L. Marina, Development of an in-capillary derivatization method by $\mathrm{CE}$ for the determination of chiral amino acids in dietary supplements and wines, Electrophoresis 30 (2009) 696-704.

[68] E. Domínguez-Vega, A. B. Martínez-Girón, C. García-Ruiz, A. L. Crego, M. L. Marina, Fast derivatization of the non-protein amino acid ornithine with FITC using an ultrasound probe prior to enantiomeric determination in food supplements by EKC, Electrophoresis 30 (2009) 1037-1045.

[69] M. Castro- Puyana, C. García-Ruiz, A. L. Crego, M. L. Marina, Development of a CE-MS ${ }^{2}$ method for the enantiomeric separation of L/D-carnitine: Application to the analysis of infant formulas, Electrophoresis 30 (2009) 337-348. 
[70] B. Van de Poel, I. Bulens, P. Lagrain, J. Pollet, M. L. A. T. M. Hertog, J. Lammertyn, M. P. De Proft, B. M. Nicolaï, A. H. Geeraerd, Determination of S-Adenosyl-Lmethionine in fruits by capillary electrophoresis, Phytochem. Anal. 21 (2010) 602-608.

[71] C. Simó, C. Barbas, A. Cifuentes, Chiral electromigration methods in food analysis, Electrophoresis 24 (2003) 2431-2441.

[72] G. R. McKinney, The effect of certain compounds on the in-vitro synthesis of urea and its precursors, JPET 101 (1951) 345-352.

[73] E. Curis, I. Nicolis, C. Moinard, S. Osowska, N. Zerrouk, S. Bénazeth, L. Cynober, Almost all about citrulline in mammals, Amino Acids 29 (2005) 177-205.

[74] H. Jung, K. Jung, H. P. Kleber, Synthesis of L-carnitine by microorganisms and isolated enzymes, Adv. Biochem. Eng. Biotechnol. 50 (1993) 21-44.

[75] T. Bottiglieri, S-Adenosyl-L-methionine (SAMe): from the bench to the bedsidemolecular basis of a pleiotrophic molecule, Am. J. Clin. Nutr. 76 (2002) 1151S-1157S.

[76] D. O. Adams, S. F. Yang, Ethylene biogenesis-S-adenosylmethionine as and intermediate in conversion of methionine to ethylene in apple tissue, Plant Physiol. 59 (1977) 45-45 